CARLA MONTANARI MERGEL

\title{
Bioprospecção de enzimas lignocelulolíticas a partir de actinomicetos endofíticos
}

Dissertação apresentada ao Programa de Pós-Graduação Interunidades em Biotecnologia USP/Instituto Butantan/IPT, para obtenção do Título de Mestre em Biotecnologia. 


\section{Bioprospecção de enzimas lignocelulolíticas a partir de actinomicetos endofíticos}

Dissertação apresentada ao Programa de Pós-Graduação Interunidades em Biotecnologia USP/Instituto Butantan/IPT, para obtenção do Título de Mestre em Biotecnologia.

Área de concentração: Biotecnologia

Orientador: Prof. Dr. Gabriel Padilla

Versão corrigida. A versão original eletrônica encontra-se disponível tanto na Biblioteca do ICB quanto na Biblioteca Digital de Teses e Dissertações da USP (BDTD) 
DADOS DE CATALOGAÇÃO NA PUBLICAÇÃO (CIP)

Serviço de Biblioteca e Informação Biomédica do

Instituto de Ciências Biomédicas da Universidade de São Paulo

(c) reprodução total

Mergel, Carla Montanari.

Bioprospecção de enzimas lignocelulotíticas a partir de actinomicetos endofíticos / Carla Montanari Mergel. -- São Paulo, 2014.

Orientador: Prof. Dr. Gabriel Padilla.

Dissertação (Mestrado) - Universidade de São Paulo. Instituto de Ciências Biomédicas. Programa de Pós-Graduação Interunidades em Biotecnologia USP/IPT/Instituto Butantan. Área de concentração:

Biotecnologia. Linha de pesquisa: Enzimas celulolíticas.

Versão do título para o inglês: Bioprospecting lignocellulolytic enzymes from endophytic actinomycetes.

1. Enzimas celulolíticas 2. Microrganismo endofítico 3 .

Actinomycetales 4. Streptomyces 5. Celulose 6. Cana-de-açucar I. Padilla, Prof. Dr. Gabriel II. Universidade de São Paulo. Instituto de Ciências Biomédicas. Programa de Pós-Graduação Interunidades em Biotecnologia USP/IPT/Instituto Butantan III. Título. 
UNIVERSIDADE DE SÃO PAULO

Programa de Pós-Graduação Interunidades em Biotecnologia Universidade de São Paulo, Instituto Butantan, Instituto de Pesquisas Tecnológicas

Candidato(a): $\quad$ Carla Montanari Mergel.

Título da Dissertação: $\quad$ Bioprospecção de enzimas lignocelulotíticas a partir de actinomicetos endofíticos.

Orientador(a): $\quad$ Prof. Dr. Gabriel Padilla.

A Comissão Julgadora dos trabalhos de Defesa da Dissertação de Mestrado, em sessão pública realizada a ... , considerou

\section{( ) Aprovado(a) \\ ( ) Reprovado(a)}

Examinador(a): Assinatura:

Nome:

Instituição:

Examinador(a): Assinatura:

Nome:

Instituição:

Presidente: Assinatura:

Nome:

Instituição: 


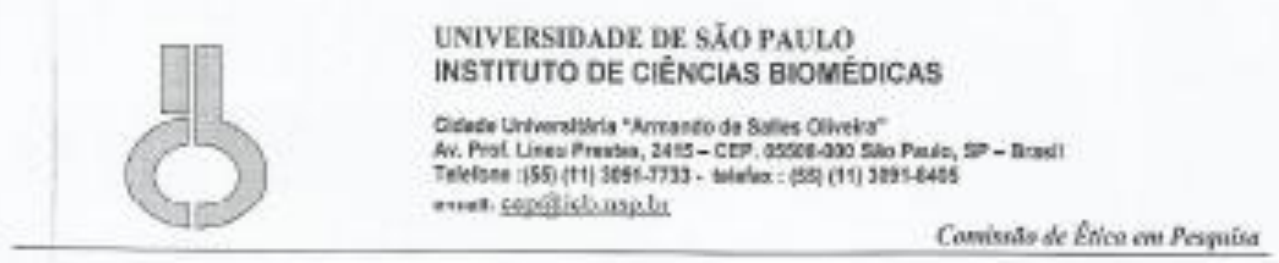

\section{CERTIFICADO DE ISENCCÃO}

Certificamos que o Protocolo CEP-ICB N 626/13 referente

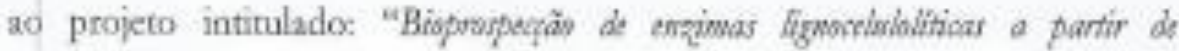

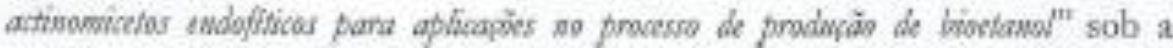
responsabalidade de Carla Montanari Mergel, foi analisado na presente data pela CEUA - COMRSAO DE ÉTCA NO USO DE ANTMAIS e pela CEPSHComissio de ÉTCa EM PEsquisa COM SEREs humanos, tendo sido deliberado que o refeñdo projeto não utilizará animais que estejam sob a Egihle dil lei 11,794 de 8 de oumbto de 2008 , nem cnvolveri procedimentos regulados pela Resolução CONEP n"466 de 2012.

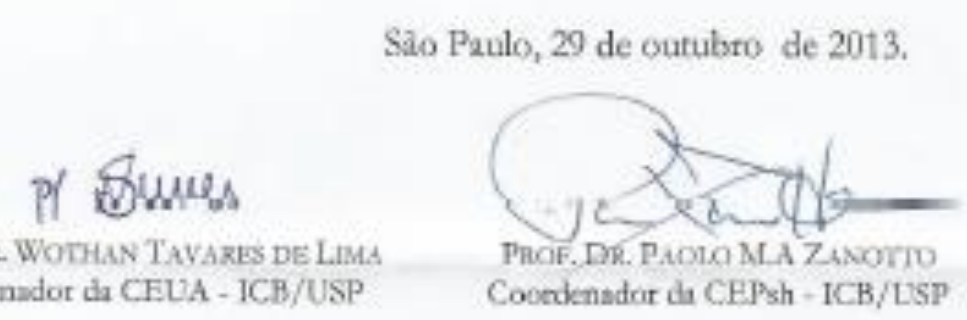




\section{AGRADECIMENTOS}

Primeiramente agradeço aos meus pais, Jorge Aparecido Mergel e Joana Montanari Mergel pelos anos incansáveis de dedicação e por estarem sempre ao meu lado, dando carinho e atenção. Aos meus irmãos, Andre e Paula por sempre me aturarem em momentos bons e críticos, assim como minha cunhada Anele. Á minha sobrinha Anya que sempre alegra e acalma meu coração. Á minha vó Regina que com seu jeitinho, e apesar de suas limitações faz sempre o possível para ajudar. Agradeço também aos outros familiares, tios, tias, primos, primas que sempre estão comigo no coração e em pensamentos!

Agradeço ao meu orientador Gabriel Padilla, por um dia ter acreditado em meu potencial, por abrir as portas de seu laboratório, pelos ensinamentos e pela amizade!

A minha mãezona do laboratório, Zita Gregório, que sempre fala coisas pertinentes para o meu bem!

Aos meus amigos e companheiros de laboratório: Aleja, Felipe, Roger, Ruth. Renata que sofreu junto comigo e ganhamos uma amiga em comum (a Sertralina), Simone que toda sexta-feira teimava em ficar no Lab até tarde comigo e terminava em pizza!! Fer Nogales, doidinha que entrou no Lab por acaso e que eu adotei!! Aos que já passaram pelo Lab 164, Fabi, Juan, Camilo, Thaisinha, Thami, Bia Bete!

Um agradecimento muito especial para Diogo Robl, meu irmão loiro, parceiro, companheiro de viagens, confidente e amigão que tem lugar garantido no meu coração!!

Aos meus amigos Ciça, Taís, Felipe, Karina, Ralph, Bubu, Bruninho, Jéssica, Letícia, Igor, Thata, Ka, Erika, Danilo, Ju, Juninho, Rosi, Paulinho que muitas vezes riram e choraram comigo, as vezes perto e as vezes longe, mas sempre comigo!!.

Agradeço aos docentes e profissionais: Sindelia Freitas Azzoni que me ajudou como uma coorientadora do trabalho, Cris Guzzo, José Geraldo da Cruz Pradella, Welington Araújo pelo apoio com equipamentos, materiais, metodologias e boas ideias.

A todos àqueles que de alguma forma colaboraram com este trabalho.

Ao CNPq pelo financiamento 


\section{RESUMO}

MERGEL, C. M. Bioprospecção de enzimas celulolíticas e hemicelulolíticas a partir de actinomicetos endofíticos. 2014. 72 f. Dissertação (Mestrado em Biotecnologia) - Instituto de Ciências Biomédicas, Universidade de São Paulo, São Paulo, 2014.

Os materiais lignocelulósicos representam cerca de $50 \%$ da biomassa terrestre, as matériasprimas de origem celulósica, contém cerca de 20 a $60 \%$ de celulose que pode ser convertida em glicose. Uma fonte abundante de material celulósico é proveniente de resíduos agroindustriais, o agroresíduo mais importante gerado no Brasil é o bagaço da cana de açúcar. $\mathrm{O}$ excedente de bagaço de cana gerado pela indústria pode ser diminuído com técnicas mais eficientes de conservação de energia produzida pela queima do bagaço, podendo ser utilizado para a produção de etanol celulósico. O objetivo desse trabalho foi a bioprospecção e identificação de enzimas celulósicas e hemicelulósicas, com ênfase para endoglicanase, $\beta-1-4-$ glicosidase, endo- $\beta$-1-4-xilanase e arabinofuranosidase, aplicáveis a indústria do bioetanol. Uma coleção com 42 linhagens de actinomicetos endofíticos e de solo passaram por uma triagem em meio sólido e por visualização de halos de hidrólise. As linhagens tiveram seus índices de hidrólise enzimática calculados pelo diâmetro do halo/ diâmetro da colônia. Além disso, o teste de difusão de esculina foi fundamental para que 12 linhagens (Streptomyces gallileus, C07, JR1, A21, E4.1, B01, A26, Streptomyces olindensis, Streptomyces lividans TK21, A14, JR3 e A22) prosseguissem para o ensaio de seleção por dosagem de atividade enzimática. $\mathrm{Na}$ fase seguinte foi realizada a triagem molecular para verificar a presença dos genes das enzimas por meio de PCR (DNA polimerase) com oligonucleotídeos degenerados, com posterior sequenciamento dos amplicons, e posterior comparação com a base de dados. Foi realizada a construção de árvores filogenéticas para complementar ensaios anteriores, Outra fase do trabalho foi composta por uma breve caracterização das enzimas xilanase e endoglicanase sob influência de quatro diferentes temperaturas $\left(40^{\circ} \mathrm{C}, 50^{\circ} \mathrm{C}, 60^{\circ} \mathrm{C}\right.$ e $\left.70^{\circ} \mathrm{C}\right) \mathrm{e}$ quatro diferentes pHs $(4,0,6,0,7,0$ e 8,0), além de gel de poliacrilamida para xilanase. Os resultados mostraram que a maioria das linhagens apresentou bom desempenho em teste em meio sólido, mas não com o teste de difusão de esculina. Nenhuma das linhagens foi capaz de hidrolisar igualmente todos os substratos testados, tendo melhores resultados para CMC ou xilana ou Licor. Quanto aos resultados para os testes da triagem molecular, as linhagens apresentaram amplicons indicando que os genes para as enzimas estão presentes. Na breve caracterização, a xilanase secretada apresentou os melhores resultados em temperaturas de $60^{\circ} \mathrm{C}$ e $70^{\circ} \mathrm{C}$, já no caso das endoglicanases as temperaturas foram mais brandas $\left(40^{\circ} \mathrm{C}\right.$, $50^{\circ} \mathrm{C}$ ), arabinofuranosidade e $\beta$-glicosidase não foram detectadas. Como conclusão pode-se considerar que os actinomicetos são potencialmente bons produtores de enzimas celulolíticas e hemicelulolíticas, sendo que neste trabalho 4 linhagens se destacaram com melhor produção para xilanase (E4.1, SoWT, C07 e A82). O material biológico é relativamente pouco estudado e não foram encontrados dados na literatura sobre o tema, mas são de interesses para estudos de obtenção de bioetanol e outros segmentos biotecnológicos.

Palavras-chave: Cana-de-açúcar. Actinomicetos. Endofíticos. Enzimas. Lignocelulolíticas. 


\begin{abstract}
MERGEL, C. M Bioprospecting cellulolytic and hemicellulolytic enzymes from endophytic actinomycetes. 2014. 72 p. Masters thesis (Biotechnology) - Instituto de Ciências Biomédicas, Universidade de São Paulo, 2014.

The lignocellulosic materials represent about $50 \%$ of the terrestrial biomass, the raw material of cellulosic origin, containing about $20-60 \%$ cellulose can be converted into glucose. An abundant source of cellulosic material is derived from organic residues, the most important ones being residues from agriculture, which are generated from Brazil's sugarcane bagasse. The surplus bagasse which is generated by the industry, could be reduced through more efficient techniques when it come to the conservation of energy which is produced by burning such bagasse, therefore being used for the production of cellulosic ethanol. The aim of this study was bioprospected and identify genes encoding for lignocellulosic enzymes, with emphasis on endoglucanase, $\beta$-1,4-glucosidase, endo- $\beta-1 \quad 4$-xylanase and arabinofuranosidase, which are applicable to the bioethanol industry. Therefore, a batch of about 42 strains of endophytic and soil actinomycetes, mostly of the Streptomyces genus, went through sorting via a solid medium, where, by the visualization of halos, some strains were selected. Moreover, the diffusion of esculin test (EDGA) was essential for other tests to be carried out, such as the total dosage of proteins. The next step was the molecular screening, where the strains previously mentioned were studied by polymerase chain reactions, with degenerate primers for each mentioned enzyme, and then a comparison was carried out between the sequences which were found in endophytic actinomycetes, and sequences previously found in databases. Therefore, phylogenetic trees were constructed for better analysis of the results, in order to respond whether the strains produced a different result or not. Another phase of the project consisted of a characterization of enzymes by polyacrylamide gel. The results demonstrated that the majority of the analysed strains presented good results when tested on solid medium, but not when tested via esculin test. The strains presented better results for a restricted number of substrates, but no strain was able to hydrolyse all substrates. Few strains presented some kind of hydrolysis on the EDGA test. With regards to the results of molecular screening, strains had amplicons, indicating that the genes for the enzymes are present. The secreted xylanase presented the best results at higher temperatures, whereas in the case of endoglucanases, the best results were found when the temperatures were milder; arabinofuranosidade and $\beta$-glucosidase were not detected. As a conclusion, it can be considered that the actinomycetes are potentially good producers of lignocellulolytic enzymes, bearing in mind that in this project, four strains showed better xylanase production. The biological material is relatively poor studied and no literature data e regarding the subject were found, but they can be considered appealing to be studied in order to obtain bioethanol and other biotech segments.
\end{abstract}

Keywords: Sugarcane. Actinomycetes. Endophytics. Enzymes. Lignocellulolytic. 


\section{LISTA DE ILUSTRAÇÕES}

Figura 1 - Esquema representativo de uma estrutura de xilana e o sítio de ataque por enzimas

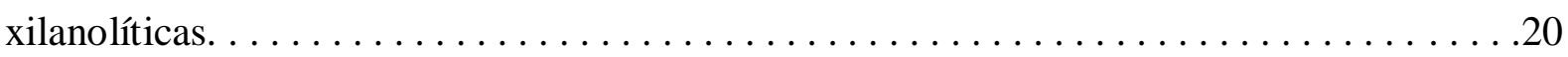

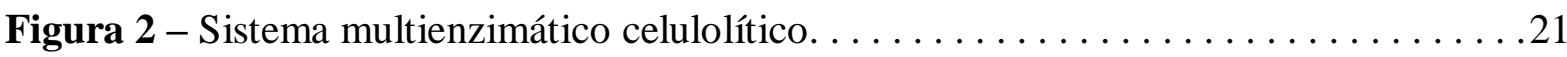

Figura 3 - Duas linhagens de actinomicetos endofíticos crescidas em meio ISP $2 \ldots \ldots 32$

Figura 4 - Streptomyces olindensis, modelo utilizado no laboratório. . . . . . . . . 33

Figura 5 - Teste com meio de farelo de trigo e duas colorações. . . . . . . . . . . . . 34

Figura 6 - Placas com crescimento de linhagens em meio com farelo de trigo e dois tipos de

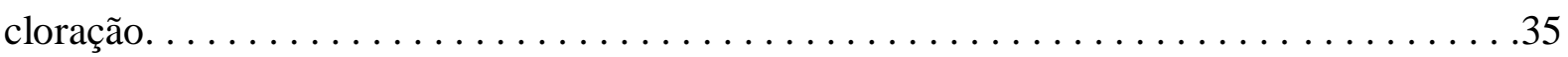

Figura 7 - Meio de seleção sem fonte de carbono coradas com corante Lugol e com

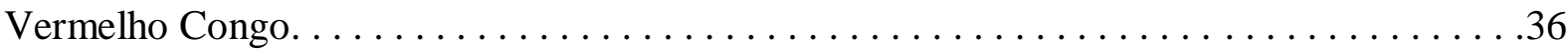

Figura 8 - Atividades enzimáticas de 12 linhagens bacterianas. . . . . . . . . . 40

Figura 9 - Árvore filogenética de linhagens de actinomicetos para endoglicanases. . . . . . . .

Figura 10 - Árvore filogenética de linhagens de actinomicetos para $\beta$-glicosidases. . . . . . .

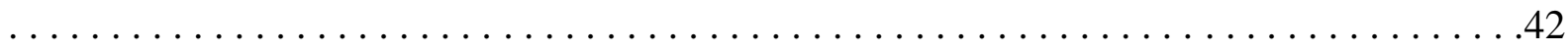

Figura 11 - Árvore filogenética de linhagens actinomicetos para xilanases. . . . . . . 43

Figura 12 - Árvore filogenética de linhagens de actinomicetos para arabinofuranosidases. . .

Figura 13 - Dosagem de atividade para temperaturas de xilanase para linhagem E4.1. . . . .

Figura 14 - Dosagem de atividade para temperaturas de xilanase para linhagem SoWT. .

Figura 15 - Dosagem de atividade para temperaturas de xilanase para linhagem C07.

Figura 16 - Dosagem de atividade para temperaturas de xilanase para linhagem A82 ..... 
Figura 17 - Dosagem de atividade para temperaturas de endoglicanase para linhagem de

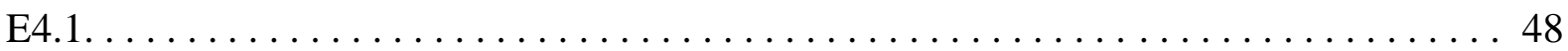

Figura 18 - Dosagem de atividade para temperaturas de endoglcanase para linhagem de

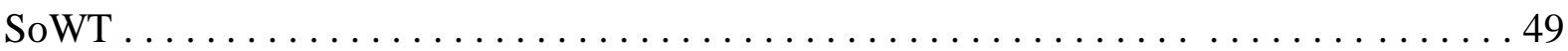

Figura 19 - Dosagem de atividade para temperaturas de endoglcanase para linhagem de C07 .

Figura 20 - Dosagem de atividade para temperaturas de endoglcanase para linhagem de A82 .

Figura 21 - Dosagem de atividade para xilanase/ $\mathrm{pH}$ todas as linhagens. . . . . . . . . 51

Figura 22 - Dosagem de atividade para endoglicanase/ $\mathrm{pH}$ todas as linhagens. . . . . . . .51

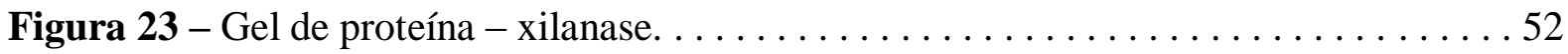




\section{LISTA DE TABELAS}

Tabela 1 - Sequências dos nucleotídeos degenerados utilizados. . . . . . . . . . 28

Tabela 2 - Índices de hidrólise das linhagens testadas $\ldots \ldots \ldots \ldots \ldots \ldots \ldots \ldots \ldots \ldots$

Tabela 3 - Padronização das temperaturas utilizadas para cada iniciador. . . . . . . . . . .41

Tabela 4 - Sequência de aminoácidos encontrados no sequenciamento de proteínas. ........

Tabela 5 - Anexo A - Identificação das linhagens de actinomicetos endofíticos por 16S ribossomal e suas fontes de isolamento. . . . . . . . . . . . . . . 66

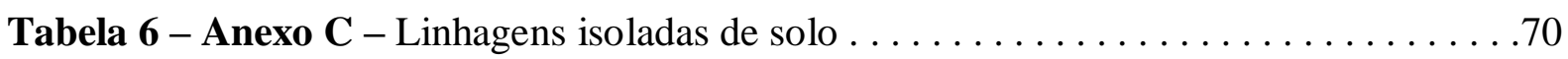

Tabela 7 - Anexo D - Comparação de temperaturas e pH de xilanases encontradas no presente trabalho e na literatura. . . . . . . . . . . . . . . . 71

Tabela 8 - Anexo E - Comparação de temperaturas e pH de endoglicanases encontradas no presente trabalho e na literatura. . . . . . . . . . . . . . . . 72 


\section{LISTA DE ABREVIATURAS E SIGLAS}

ARA - Arabinofuranosidase

BED - Bagaço de cana de açúcar pré-tratado por explosão a vapor e deslignificado

CMC- Carboximetilcelulose

EDGA - Gel de difusão de esculina

END - Endoglicanase

FS - Farelo de soja

IE - Índice enzimático

ISP2 - "International Streptomyces Project Medium (Number 2)"

NCBI - "National Center for Biotechnology Information"

UI - Unidades internacionais

XIL - Xilanase

YEME - "Yeast Extract-Malt Extract Medium" 


\section{SUMÁRIO}

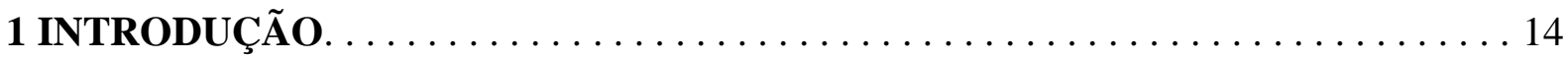

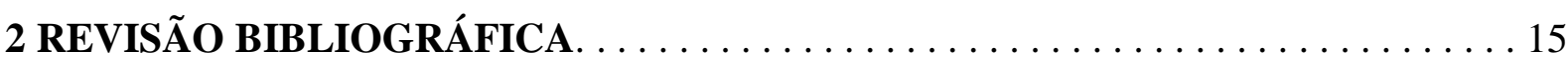

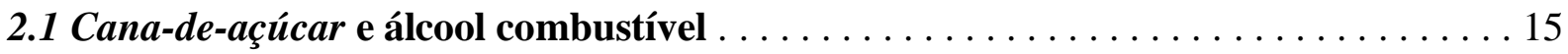

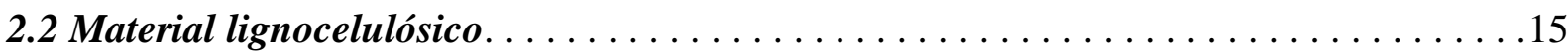

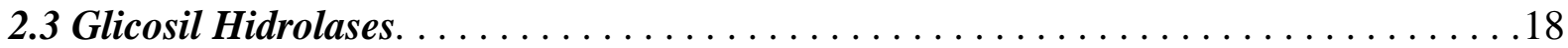

2.3.1 Xilanases . . . . . . . . . . . . . . . . . . . . . . . . . . . . . . . . . . . . 19

2.3.2 Arabinofuranosidases . . . . . . . . . . . . . . . . . . . . . . . . . . . 19

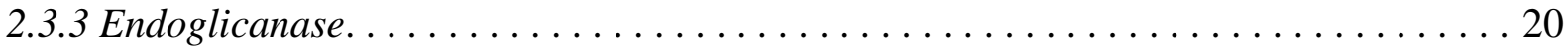

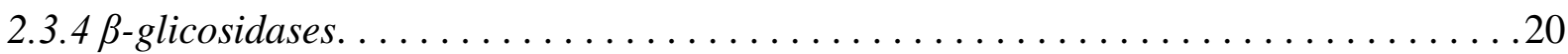

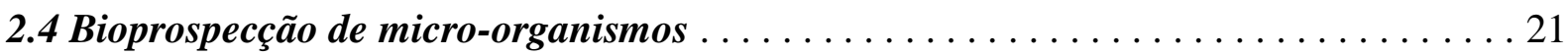

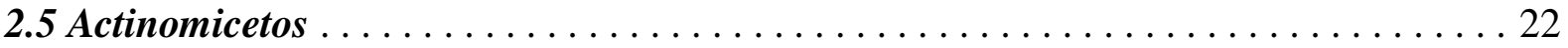

3 HIPÓTESES. . . . . . . . . . . . . . . . . . . . . . . . . . . . 24

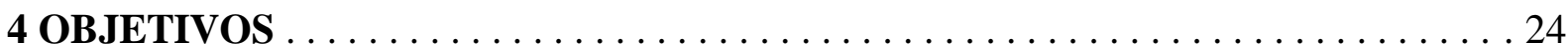

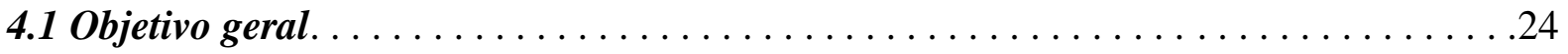

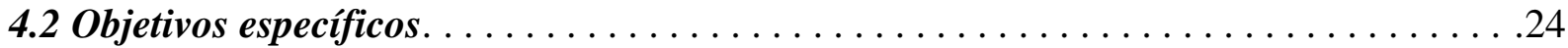

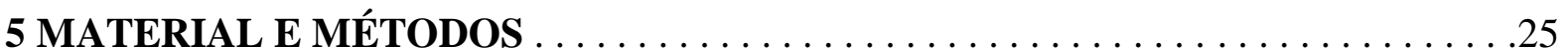

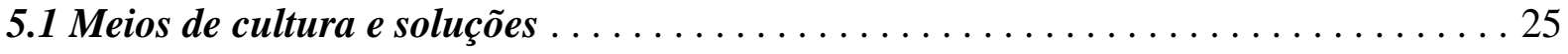

5.2 Recuperação e manutenção das linhagens dos actinomicetos . . . . . . . . . . 25

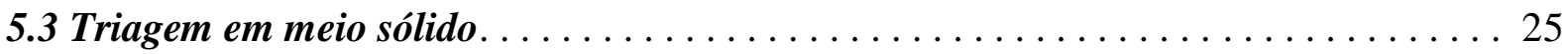

5.3 .1 Padronização de triagem em meio sólido.......................... 25

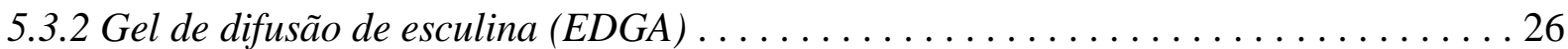

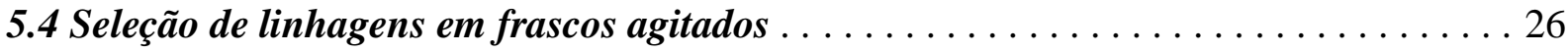

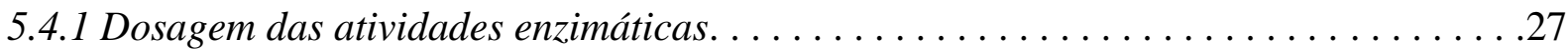

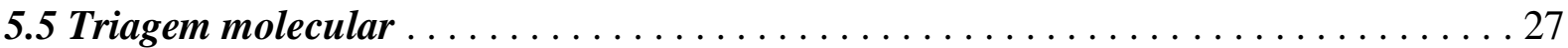

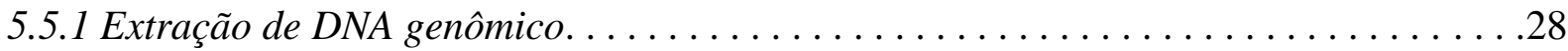

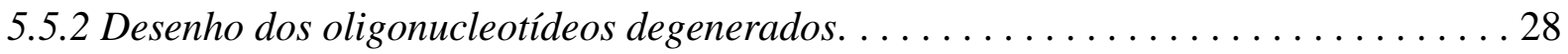

5.5 .3 Reação em cadeia da Polimerase . . . . . . . . . . . . . . . . . . . . . . . . . . .29

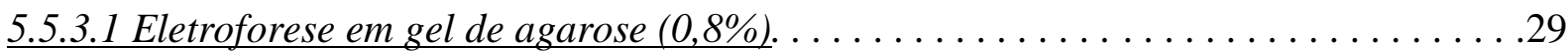

5.5.3.2 Purificação dos fragmentos e sequenciamento . . . . . . . . . . . . . . . . . 29

5.5 .4 Árvores filogenéticas. . . . . . . . . . . . . . . . . . . . . . . . 30 


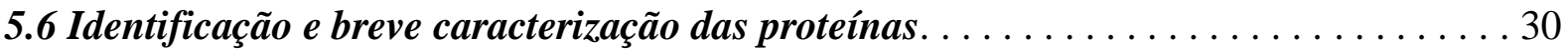

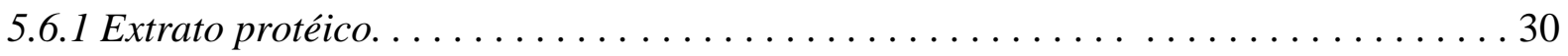

5.6.1.1 Eletroforese em gel de poliacrilamida $(S D S-P A G E 12 \%) \ldots \ldots \ldots \ldots \ldots \ldots$

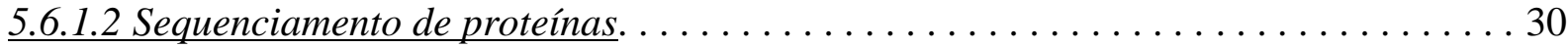

5.6.2 Caracterização da Temperatura e pH das enzimas celulolíticas em linhagens de

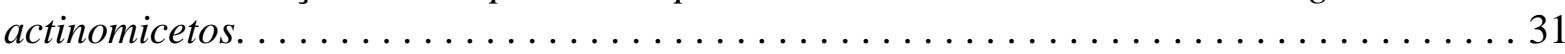

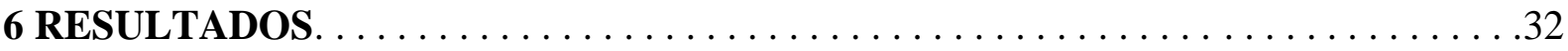

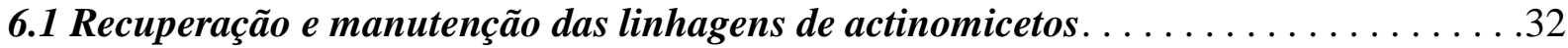

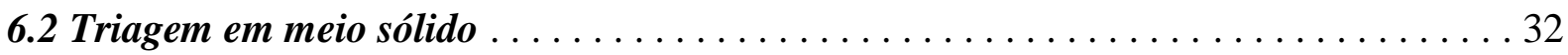

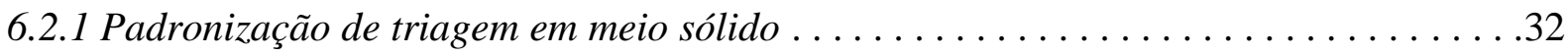

6.2.2 Seleção das linhagens em meio sólido e teste de difusão de esculina (EDGA). . . . . . 36

6.2 .3 Seleção dos actinomicetos em frascos agitados . . . . . . . . . . . . . . . . . 39

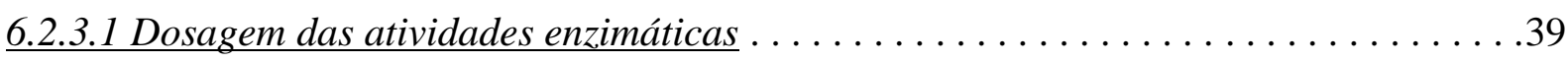

6.3 Triagem com primers degenerados para detecção dos possíveis genes que codificam

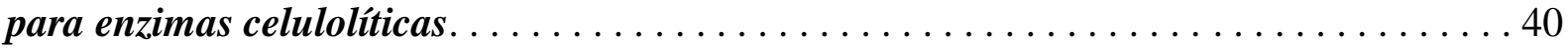

6.3 .1 Iniciadores degenerados e Reação em Cadeia da Polimerase (PCR) . . . . . . . . . 40

6.3.2 Árvores filogenéticas dos genes que codificam para a síntese de enzimas celuloliticas. . .

6.4 Caracterização das enzimas por meio da medição das atividades sob influência de diferentes temperaturas e pHs utilizando extrato protéico . . . . . . . . . . . . . 45

6.4.1 Influência da temperatura e pH nas atividades das enzimas celulolíticas em linhagens

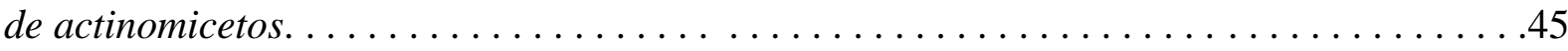

6.4.1.1 Influência da temperatura na atividade de xilanase. . . . . . . . . . . . . . . .45

6.4.1.2 Influência da temperatura na atividade de endoglicanase . . . . . . . . . . . 48

6.4.1.3 Influência do pH na atividades de xilanases e endoglicanases. . . . . . . . . . . 51

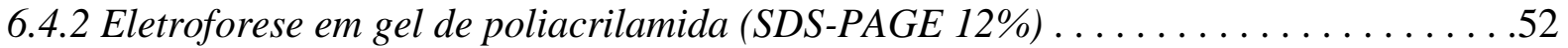

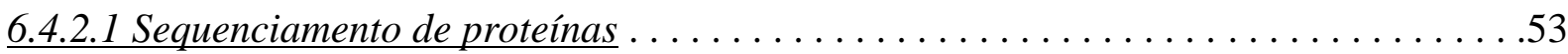

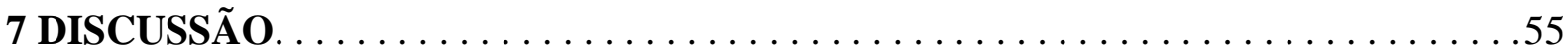

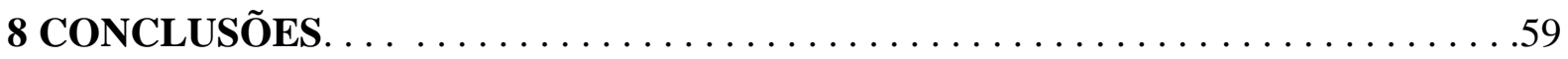

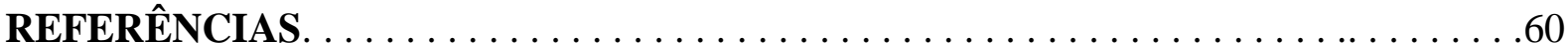

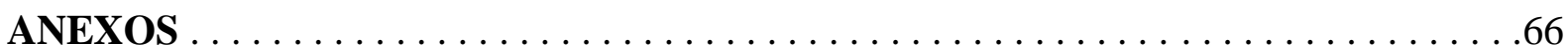




\section{INTRODUÇÃO}

O consumo crescente de combustíveis fósseis como o petróleo, carvão e gás natural, corresponde a cerca de $80 \%$ da demanda global (MATSUOKA, 2009), resultando em índices crescentes na emissão de $\mathrm{CO}_{2}$ e favorecendo o aquecimento global, principal causa para as mudanças climáticas no mundo (SIMMONS et al., 2008). Um combustível alternativo deve não só trazer benefícios ambientais em relação aos combustíveis fósseis, mas ser economicamente competitivo com ele, e produzido em quantidades suficientes para fazer um significativo impacto sobre a demanda de energia (HILL, J et al., 2006).

Devido aos fatos apresentados, muitos países estão constantemente buscando novas fontes alternativas de combustível (MARTINELLI \& FILOSO, 2008). Países como Brasil, Estados Unidos, China, Austrália, Nova Zelândia, e muitos pertencentes à União Europeia buscam por biocombustíveis obtidos de diferentes fontes renováveis, reduzindo assim a emissão de $\mathrm{CO}_{2}$ e procurando ser economicamente viáveis (SIMMONS et al., 2008).

Dentre as fontes alternativas de energia renovável, a energia eólica, solar e geotérmica correspondem hoje a uma parcela insignificante do consumo global de energia (CHU, et al., 2007 apud MATSUOKA et al., 2009). Além destas fontes, o etanol combustível, obtido a partir de cana-de-açúcar apresenta-se como uma das mais importantes e estudadas fontes alternativas de biocombustível no mundo. O Brasil, além de ser um dos líderes na produção de etanol também contribui significativamente para a redução da emissão de $\mathrm{CO}_{2}$ na atmosfera (MATSUOKA et al., 2009). O país apresenta inúmeras vantagens como a sua grande área territorial, abundante fonte de água e radiação solar para o cultivo de cana-deaçúcar. Além disso, o álcool combustível é estudado e produzido no país há mais de 30 anos (MARTINELLI \& FILOSO, 2008).

Com base nos fatos apresentados, a procura por novas enzimas lignocelulolíticas com aplicação na busca do etanol de segunda geração é uma tendência global. Esse processo de produção de etanol celulolítico, por hidrólise enzimática, se enquadra nos princípios de sustentabilidade e preservação do meio ambiente, já que, é um processo enzimático limpo, sem geração de produtos tóxicos, baixo consumo de energia e ecologicamente correto. As enzimas lignocelulolíticas que participam desse processo podem ser consideradas "enzimas verdes". Essas enzimas têm como vantagens, além da redução dos resíduos gerados pela agroindústria, um aumento de produção do etanol sem um aumento de áreas plantadas de 
cana-de-açúcar, o que também leva a um processo econômico favorável a agricultores, produtores de etanol, população e governo.

\section{REVISÃO BIBLIOGRÁFICA}

\subsection{Cana-de-açúcar e álcool combustível}

Historicamente, a cana de açúcar é um dos principais produtos agrícolas do Brasil, sendo cultivada desde a época da colonização. Do seu processo de industrialização obtêm-se como produtos o açúcar, nas suas mais variadas formas e tipos, o álcool (anidro e hidratado), o vinhoto e o bagaço. Devido à grandeza dos números do setor sucroalcooleiro no Brasil, não se pode tratar a cana-de-açúcar, apenas como mais um produto, mas sim como o principal tipo de biomassa energética, base para todo o agronegócio sucroalcooleiro. (http://infoener.iee.usp.br/scripts/biomassa/br_cana.asp, acesso em novembro de 2014).

No ano de 2014, estimativas da safra de 2013/2014 apontam que o Brasil produziu 658.697,55 (mil) toneladas de cana-de-açúcar e teve uma área plantada de 8.811,43 (mil) hectares. O Estado de São Paulo é o que apresenta os maiores valores, respondendo por 50\% de toda a plantação de cana do país. (SILVA et al., 2007 apud MARTINELLI; FILOSO, 2008).(http://www.udop.com.br/download/estatistica/area_cultivada/21out14_\%20area_produ tividade_brasil.pdf, acesso em novembro de 2014).

Segundo a União da Indústria de cana-de-açúcar (UNICA, acesso em março de 2013), a história do álcool combustível, iniciou-se em 1975 com o Programa Nacional do Álcool (PROÁLCOOL) que foi o passo inicial do que hoje é considerado o mais importante e bemsucedido programa de combustível comercial renovável já implantado no mundo. Lançado por decreto presidencial, o PROÁLCOOL incentivou a oferta em grande escala de etanol produzido de cana-de-açúcar, mandioca e outros insumos, aproveitando-se da experiência acumulada do Brasil desde a década de 20 com a produção e utilização do etanol combustível em menor escala. Ainda, segundo o mesmo instituto, o primeiro "choque do petróleo" em 1973, que causou forte aumento no preço do barril de petróleo, foi o principal estímulo para o lançamento do PROÁLCOOL. Na época, a maior parte do petróleo utilizado no Brasil era importada, e a elevação no preço do petróleo teve forte impacto nas contas externas brasileiras. Dados de 2007-8 conferem que a produção brasileira de etanol ilustrou o sucesso do programa. Dados de 1975-76 apontam que a produção de etanol em litros, foi de 555 
milhões, já em 2007-08 esse número teve um aumento significativo, crescendo para mais de 20 bilhões de litros.

Para o Brasil continuar sendo um dos líderes mundiais no cultivo de cana, faz-se necessário investimento constante para a geração de novas tecnologias e formação de competências (BUCKERIDGE et al., 2008). Neste sentido a utilização de material lignocelulósico ou biomassa, torna-se uma alternativa atrativa para a obtenção de etanol, onde se estima, por exemplo, o aumento da produção de etanol sem aumento de áreas plantadas. Este produto, intitulado de etanol de segunda geração, utiliza como matéria-prima, resíduos da agroindústria que, após o tratamento enzimático, gera açúcares fermentáveis. Em alguns países da Europa e nos Estados Unidos por não possuírem as vantagens do Brasil (condições climáticas e área disponível), a pesquisa visando à obtenção de etanol a partir de diversos materiais lignocelulósicos, tem sido bastante priorizada (BON et al., 2008).

\subsection{Material lignocelulósico}

Segundo Sarko (1997) os materiais lignocelulósicos são considerados os compostos mais abundantes na biosfera, representando $50 \%$ da biomassa terrestre. Estes materiais são compostos por uma matriz dura e fibrosa, onde as fibras flexíveis, celulose, hemicelulose e pectina são embebidas por uma matriz de lignina (BON et al., 2008). As matérias-primas de origem celulósica contêm de 20 a $60 \%$ de celulose, que pode ser totalmente convertida em glicose (CASTRO; JUNIOR, 2010).

A celulose, um dos componentes destes materiais lignocelulósicos, é um polímero linear contendo 15000 unidades de D-glicose unidas por ligações glicosídeas B-1,4. Uma das características desta fonte de carbono é o elevado grau de cristalinidade o que confere essa molécula resistência à hidrólise (ZHANG; LYND, 2004).

Já a hemicelulose consiste em um conjunto de cadeias ramificadas de açúcares cujas unidades incluem aldopentoses (xilose e arabinose) e aldo-hexoses (glicose, manose e galactose). Uma das características deste polissacarídeo é a sua ligação entre glicose e a lignina e a presença de diferentes unidades monoméricas que contribuem para a complexidade da estrutura da hemicelulose e suas diferentes composições (JACOBSEN, 2000). Diferentemente da celulose, as hemiceluloses não possuem regiões cristalinas ficando mais suscetíveis à hidrólise ácida.

Em muitos locais no país há um considerável excedente na atividade agroindustrial. Materiais como os resíduos da indústria madeireira, palha e sabugo de milho, palha de trigo, 
palha de arroz, palha de coco, entre outros representam a diversidade destes substratos renováveis e colocam o país em destaque para alcançar a liderança na geração de etanol a partir de biomassa (BON et al., 2008). Outro importante resíduo da agroindústria brasileira é o bagaço da cana-de-açúcar. O bagaço gerado nas usinas pode ser aproveitado na cogeração de energia, entretanto, a estocagem e a poluição ambiental são apresentadas como sérios problemas para utilização deste resíduo. Mesmo com a utilização do bagaço para gerar energia, ainda há um excedente deste resíduo, cerca de $12 \%$, que pode ser utilizado como biomassa para formar o etanol de segunda geração em nosso país (BON et al., 2008; SAHA, 2003).

Em 2005, segundo a Dedini, acesso em 2014, o excedente de bagaço de cana gerado pela indústria sucro-alcooleira foi de 16 milhões de toneladas. Esse excesso de biomassa pode ser diminuído com técnicas mais eficientes de conservação da energia produzida pela queima do bagaço, podendo ser utilizado para a produção de etanol celulósico (MACEDO; NOGUEIRA, 2005). Segundo Pandey et al. (2000) a composição do bagaço se da por $50 \%$ de celulose, $25 \%$ de hemicelulose e os $25 \%$ restantes por lignina. Atualmente a hidrólise do bagaço de cana pode ser catalisada por ácidos ou enzimas celulolíticas (MARTIN et al., 2002). A hidrólise enzimática depende de enzimas comerciais, o que aumenta o custo para o processo, porém é vantajosa quando comparada com a hidrólise ácida, pois essa gera uma mistura complexa de substâncias tóxicas, na qual se incluem acetatos, furanos, ácidos alifáticos, compostos fenólicos e aromáticos, que podem prejudicar o metabolismo celular causando dano aos micro-organismos e meio ambiente (BON et al, 2008; CARVALHO LIMA, 2001). Portanto, os custos da hidrólise enzimática são menores quando comparados com a de hidrólise ácida ou alcalina, pois normalmente a hidrólise enzimática é conduzida sob condições brandas de pH e temperaturas e não apresenta problemas com corrosão (SINGH et al., 2009). A fim de minimizar os custos de produção torna-se necessária a identificação das enzimas mais eficientes e a otimização de suas proporções a fim de reduzir a quantidade de enzima utilizada, sem prejudicar o rendimento ou reduzir significativamente a taxa de hidrólise (GAO et al., 2010).

As celulases, produzidas por micro-organismos, são compostas por uma mistura de enzimas que apresentam especificidade para as ligações glicosídeas ß-1,4. Estas enzimas necessitam de um sinergismo para atuar na molécula de celulose formando moléculas de glicose. Com o desenvolvimento de pré-tratamentos envolvendo enzimas, como as celulases, 
a busca por hemicelulases eficazes é uma tendência para a obtenção de etanol de segunda geração (BON et al. 2008; BUCKERIDGE et al., 2008).

Para a hidrólise das hemiceluloses, as xilanases são apontadas como uma das principais enzimas para a hidrólise da xilana (POLIZELI et al., 2005). Além dela a enzima feruloil esterase, é considerada de extrema importância pois atua na desconstrução da biomassa através da degradação de diferentes ligações covalentes intra e interpoliméricas. Esta enzima possui a capacidade de romper as ligações entre lignina e a hemicelulose, facilitando o acesso das celulases à fibra de celulose (BON et al., 2008) e foi primeiramente descrita em um actinomiceto (Streptomyces sp.) por Mackenzie et al., (1987).

\subsection{Glicosil hidrolases}

Enzimas capazes de hidrolisar ligações entre carboidratos e seus derivados são denominadas glicosil hidrolases. A hidrólise de ligações glicosídicas, é fundamental para a absorção de energia Esta hidrólise ocorre por meio de dois mecanismos principais, ou uma retenção total ou uma inversão da conFiguração anomérica. Em ambos os mecanismos, a posição dos prótons é idêntica, ou seja, há uma curta distancia das ligações de hidrogênio e do oxigênio glicosídico (DAVIES; HENRISSAT, 1995)

Segundo Davies e Henrissat, 1995, são pequenas características que definem o tipo de glicosil hidrolase, principalmente por detalhes na sua estrutura tridimensional. A hidrólise da celulose é obtida por várias glicosil hidrolases que atuam em sinergia. Endoglicanases (EC 3.2.1.21), que hidrolisam ligações glicosídicas no interior da cadeia, principalmente nas regiões amorfas, liberando fragmentos menores; celobiohidrolases (EC 3.2.1.91), que hidrolisam ligações glicosídicas nas extremidades da cadeia, liberando dímeros de glicose (celobioses); $\beta$-glicosidases (EC 3.2.1.21), que hidrolisam as celobioses, liberando unidades de glicose (ARO et al., 2005).

Devido à estrutura variável e complexa organização das hemiceluloses com a celulose e lignina, a completa degradação da hemicelulose exige a ação combinada de diversas enzimas como endoenzimas, exoenzimas e enzimas auxiliares. Os principais grupos de enzimas são xilanases, $\beta$-mananases, $\alpha$-L-arabinofuranosidases, $\alpha$-D-glucuronidases, $\beta$ xilosidases e esterases hemicelulolíticas (SHALLOM; SHOHAM, 2003).

As xilanas por apresentarem heterogenicidade estrutural, são hidrolisadas com a ação de pelo menos dois grupos de enzimas, endo 1,4- $\beta$-xilanases (EC 3.2.1.8) e $\beta$-xilosidases (EC 
3.2.1.37), atuando na cadeia principal. Dependendo do tipo de xilana, podem ser também necessárias enzimas auxiliares para a clivagem das cadeias laterais, como $\alpha$-Larabinofuranosidases (EC 3.2.1.55), $\alpha$-glucuronidases (EC 3.2.1.131), acetil-xilana-esterases (EC 3.1.1.72), ácido ferúlico esterases (E.C.3.1.1.73) entre outras (ARO et al., 2005).

\subsubsection{Xilanases}

Xilanases são enzimas hidrolíticas que clivam ligações $\beta-1,4$ do complexo polissacarídeo da parede celular das plantas. Dentro do sistema de classificação, as xilanases são normalmente reportadas como sendo pertencentes às famílias 10 e 11, Mas, estudos mostram que as famílias 5,7,8 e 43 também podem conter domínios catalíticos de uma endo1,4- $\beta$-xilanase (COLLINS, GERDAY; FELLER, 2005). A Figura 1 aponta uma cadeia xilanolítica e a ação das enzimas.

\subsubsection{Arabinofuranosidase}

As $\alpha$-L-arabinofuranosidases (EC3.2.1.55) são enzimas acessórias que clivam as ligações $\alpha$-L-arabinofuranosídica e atuam em sinergia com outras hemicelulases para a hidrólise completa de hemicelulose. As $\alpha$-L-AFases são enzimas envolvidas na hidrólise de ligações de L-arabinose. Tal hidrólise enzimática liberta substratos solúveis, que são utilizados por ambos os micro-organismos procariotas e eucariotas (NUMAN; BHOSLE, 2006). A Figura 1 também aponta a ação de uma $\alpha$-L-arabinofuransidase 
(a)

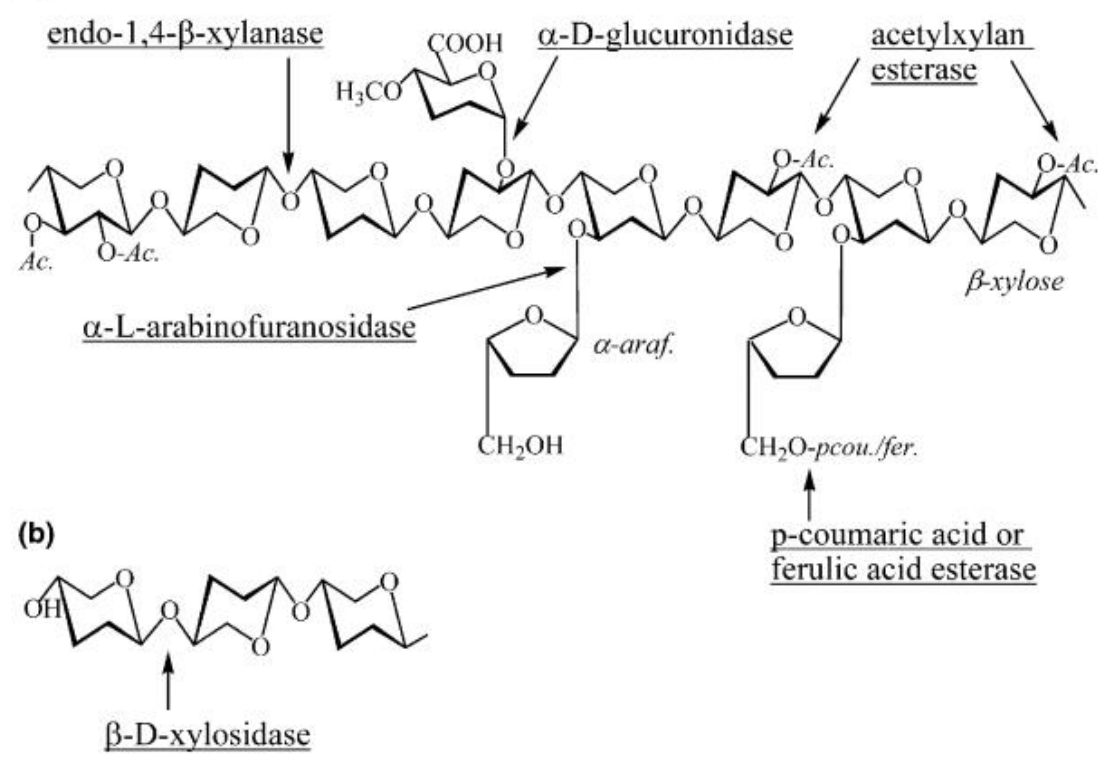

Figura 1 - (a) Estrutura de uma xilana e os sítios de ataque por enzimas xilanolíticas; (b) Hidrólise de xilo-oligossacarídeo por $\beta$-D-xilosidase. (COLLINS, GERDAY; FELLER, 2005)

\subsubsection{Endoglicanase}

Endoglicanases são geralmente consideradas como sinergicamente envolvidas nas fases iniciais da decomposição de celulose, um passo essencial no biotratamento de materiais lignocelulósicos das plantas em etanol (YENNAMALLI et al., 2011). A endoglicanase age de forma aleatória, clivando ligações beta, dentro da molécula da celulose; a celobiohidrolase remove as unidades de celobiose a partir das extremidades da cadeia da celulose (LEE et al., 2002). A Figura 2 aponta uma cadeia de celulose e a ação das enzimas sobre ela.

\subsection{4. $\beta$-Glicosidase}

$\beta$-glicosidases são enzimas que catalisam a transferência formal de grupos de glicose. Sob condições fisiológicas, uma reação de transferência geralmente resulta na hidrólise de uma ligação $\beta$-D-glicosídica. $\beta$-glicosidases, mais especificamente celobiases, tem sido referido como uma das três classes de enzimas que constituem sistema celulolítico (PEREZPONS et al., 1994). A Figura 2, mostra a ação da celobiase ou $\beta$-glicosidase. 


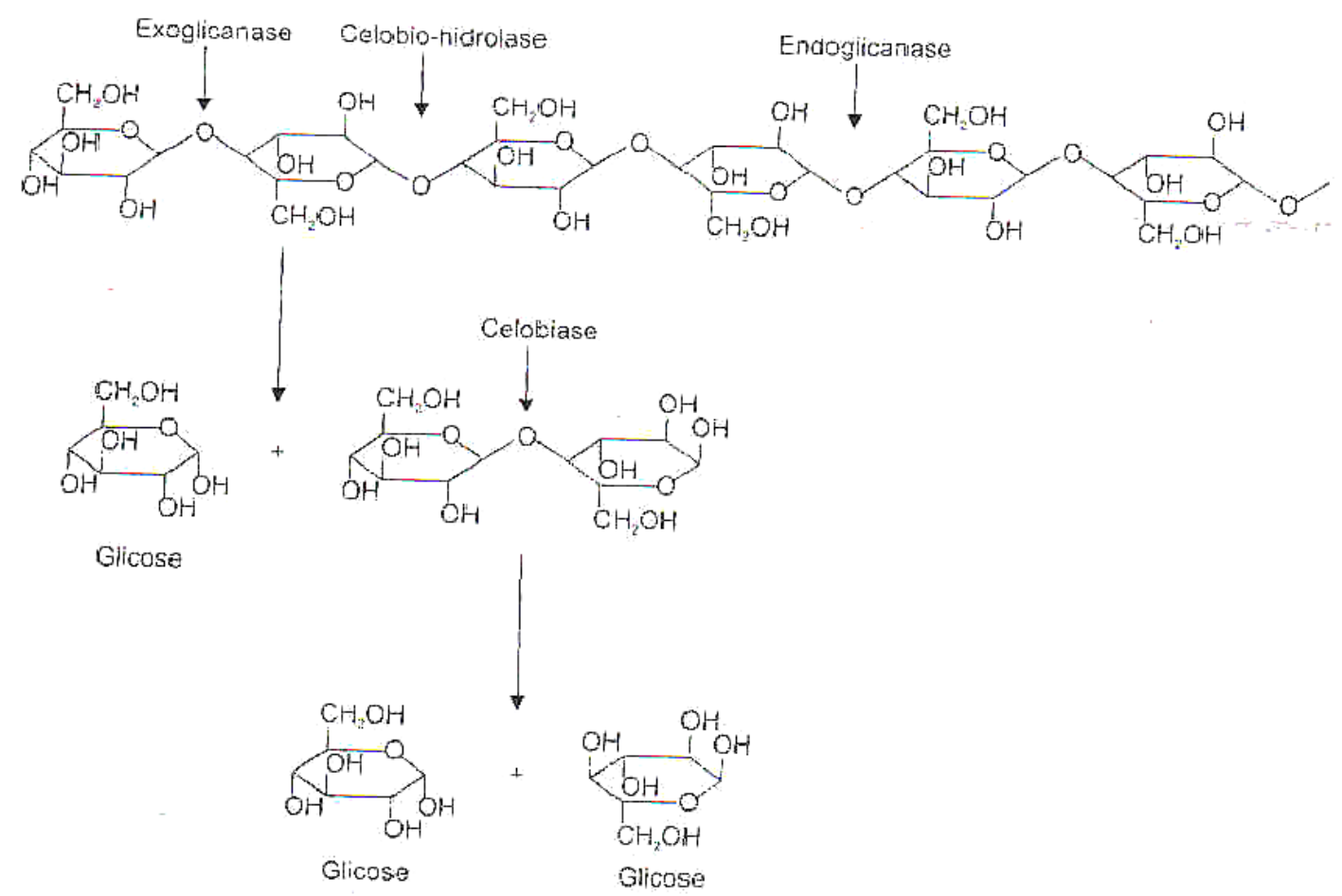

Figura 2 - Sistema multi enzimático do sistema celulolítico (BON et al., 2008)

\subsection{Bioprospecção de Micro-organismos}

A bioprospecção fundamenta-se no estudo de micro-organismos para a obtenção de inúmeros produtos com aplicações industriais. Sabe-se que este grupo de organismos contém a maior fonte de genes do planeta. Em termos de números o total de biomassa celular observada é de $6 \times 10^{30}$ pertencentes ao grupo da bactéria, $1,3 \times 10^{28}$ de arquea e $3,1 \times 10^{29}$ de eucariotos. O Brasil detém cerca de $20 \%$ de toda esta diversidade microbiana (SOUZA et al., 2004).

Uma parcela destes micro-organismos, principalmente as bactérias e os fungos, possuem a capacidade de colonizar o interior de diversas plantas. Estes micro-organismos são chamados de endofíticos. Os micro-organismos endofíticos são responsáveis por colonizar plantas sem causar danos aparentes aos seus hospedeiros (AZEVEDO, 1998). Esta interação entre o micro-organismo e a planta ainda não está totalmente elucidada, entretanto sabe-se que a promoção de crescimento vegetal e a formação de antibióticos contra fitopatógenos são algumas vantagens atribuídas a esta interação (AZEVEDO; 1998; El-TARABILY, 2003; FUENTES-RAMIREZ et al., 1993).

Endofíticos podem ser excelentes fontes de enzimas hidrolíticas. Evidentemente, 
durante a fase endofítica, a utilização destas enzimas deve estar relacionada com a relação mutualística com a planta hospedeira (MOY et al., 2002).

No entanto, embora a associação entre plantas e micro-organismos endofíticos seja ecologicamente importante, pouco se sabe sobre as características fisiológicas da interação. Uma consideração importante é a variedade de substratos que podem ser utilizados por esses micro-organismos. Estudos têm demonstrado que endofiticos são capazes de metabolizar in vitro a maioria dos substratos encontrados em plantas, e produzir enzimas incluindo proteases, amilases, lipases, oxidases, fenol lacases, oxidases de polifenol, celulases, xilanases, mananases, e liase de pectina (LUMYONG et al., 2002; SCHULZ; BOYLE, 2005). Um grupo de micro-organismos que tem recebido especial atenção e está inserido na classe de microorganismos endofíticos são os actinomicetos.

\subsection{Actinomicetos}

Actinomicetos são bactérias filamentosas gram-positivas e amplamente encontradas no solo (COELHO; NASCIMENTO, 2008). Alguns trabalhos encontrados na literatura evidenciam a interaçãoos actinomicetos com plantas, principalmente quando há produção de antibióticos (AZEVEDO 1998; COOMBS; FRANCO 2003; STROBEL et al., 2004).

Os actinomicetos são alvo de diversos estudos que buscam novos produtos de interesse industrial como enzimas, antibióticos e outras substâncias bioativas, especialmente o gênero Streptomyces sp. (ANDERSON; WELLINGTON, 2001). Enzimas pertencentes à classe das celulases e xilanases tem sido encontradas em alguns actinomicetos por apresentarem ampla diversidade ecológica e bioquímica, além de ter a capacidade de produzir metabólitos secundários (COELHO; NASCIEMENTO, 2008). Segundo Suleman et al. (2002), a diversidade deste grupo para a produção de enzimas é tão grande que já existe no mercado ao menos um produto (Mycostop) responsável por aumentar a imunidade vegetal contra fitopatógenos utilizando enzimas como a xilanase, celulase e quitinase.

As celulases produzidas por actinomicetos apresentam características superiores daquelas observadas em fungos, dentre elas a estabilidade da enzima e a alta atividade sob condições de pH e temperatura mais extremas (COELHO; NASCIMENTO, 2008; LIMA et al., 2005). Além do gênero Streptomyces sp., muitos Thermomonospora sp. também são apresentados como potenciais produtores de celulases (GEORGE et al., 2001; WALDRON et al., 1986; WILSON, 1992). A hidrólise de hemicelulose mediada por xilanases também é 
amplamente estudado e conhecido em actinomicetos. A espécie mais estudada é Streptomyces lividans por já apresentar um sistema xilanolítico caracterizado. Torna-se evidente que, devido à diversidade deste grupo, muitos de seus representantes possuem a capacidade de secretar xilanases sob diferentes condições de cultivo (temperatura entre $50-75^{\circ} \mathrm{C}$ e pH 7.09.0) (COELHO; NASCIMENTO, 2008). 


\section{HIPÓTESES}

- Actinomicetos podem produzir uma vasta gama de enzimas celulolíticas e lignocelulolíticas;

- As atividades celulolíticas e hemicelulolíticas dos actinomicetos podem ser mais altas comparadas as já encontradas hoje no mercado;

- As enzimas de actinomicetos são superiores as de fungos.

\section{OBJETIVOS}

\subsection{Objetivo Geral}

O objetivo geral deste projeto é bioprospectar e identificar enzimas celulolíticas e hemicelulolíticas, com ênfase em: endoglicanase, $\beta$ - 1,4-glicosidase, endo- $\beta$ 1,4-xilanase e arabinofuranosidase, aplicáveis à indústria do bioetanol.

\subsection{Objetivos específicos}

- Bioprospectar enzimas lignocelulolíticas por meio de uma coleção de cultura de actinomicetos endofíticos, embora, alguns de solo também foram utilizados, incluindo Streptomyces olindensis (organismo modelo no Laboratório de Bioprodutos)

- Selecionar as melhores linhagens produtoras das enzimas de interesse;

- Quantificar as atividades enzimáticas dos micro-organismos selecionados

- Avaliar as melhores condições de atividade sob influência de diferentes temperaturas e pH. 


\section{MATERIAL E MÉTODOS}

Este estudo foi realizado a partir de uma coleção de actinomicetos pertencentes ao Laboratório de Bioprodutos (ICB/ USP). Foram bioprospectados 42 actinomicetos isolados de: Citrus reticulate, Citrus sinenses, Theobroma cacao, Glycine max, Saccharum officinarum, Cataranthus roseus e de solo. As linhagens foram previamente identificadas por Andrielli, 2010, por meio da amplificação e sequenciamento do gene 16S rRNA. A listagem das linhagens encontra-se no item anexo (Anexo A).

\subsection{Meios de cultura e soluções}

A lista de meios de cultura e soluções que foram utilizados no presente trabalho, encontra-se em anexo B, juntamente com suas formulações.

\subsection{Recuperação e manutenção das linhagens dos actinomicetos}

As linhagens de actinomicetos foram recuperadas de culturas congeladas e posteriormente preservadas em glicerol. Para tanto, as linhagens foram crescidas em caldo ISP2 e colocadas sob agitação a temperatura de $28{ }^{\circ} \mathrm{C}$ durante 2 dias para sua reativação. Após o período de dois dias, uma quantidade de 100uL do cultivo foi transferida para placas de Petri contendo o meio ISP2 com ágar comercial. As amostras foram espalhadas com alças de vidro a fim de preencher toda a superfície do meio com as referidas amostras, que foram incubadas também a $28{ }^{\circ} \mathrm{C}$ por um período de 14 dias, onde as amostras conseguiam atingir uma quantidade visível de esporos.

A partir do abundante crescimento as linhagens foram preservadas. As placas de crescimento das amostras foram individualmente raspadas com auxílio de alças de platina, dessa maneira, desprendendo-se os esporos e o micélio dos actinomicetos. O sedimento desprendido foi ressuspendido em solução de glicerol $20 \%$ e distribuídos em microtubos. As suspensões foram mantidas à temperaturas de $-20^{\circ} \mathrm{C}$ e $-80{ }^{\circ} \mathrm{C}$.

\subsection{Triagem em meio sólido}

\subsubsection{Padronização de triagem em meio sólido}

Para seguir o objetivo desse trabalho, fez-se necessário uma padronização com meios de cultura para a posterior seleção dos micro-organismos, três meios foram testados e estão descritos no item Meios de Cultura e Soluções do Anexo B. O primeiro meio modificado de Silva e Gouveia, (2008), o segundo meio foi descrito por Kasana et al., (2008) e o terceiro 
meio foi adaptado de Nascimento et al., (2002), em todos os casos a fonte de carbono variou de acordo com os experimentos. $\mathrm{O}$ pH dos meios foram corrigidos para 7,0 e então foram autoclavados a $121^{\circ} \mathrm{C}$ por 20 minutos. Assim, as fontes de carbono poderiam ser: xilana de madeira de Faia (beechwood) 0,2\% (Sigma), ou carboximetilcelulose (CMC) 0,2\% (Merck), ou pectina cítrica $0,2 \%$ (Sigma), ou licor do tratamento hidrotérmico do bagaço de cana $25 \%$, ou farelo de trigo $0,2 \%$.

As linhagens tidas como padrão (anexo C) foram inoculadas através de um único repique nos meios testados e incubados à $28^{\circ} \mathrm{C}$ por 72 horas.

Além dos meios, duas colorações para revelação dos halos de hidrólise foram testadas, uma com a adição de solução de Lugol por 5 minutos e outra com a adição de solução de Vermelho do Congo (1\%) durante quinze minutos com posterior lavagem com $\mathrm{NaCl} 1 \mathrm{M}$ por 10 minutos (KASANA et al., 2008; WOOD, et al., 1988). Os testes com as colorações visavam observar a interferência dos reveladores nos resultados obtidos. As linhagens tiveram seus índices enzimáticos medidos (Diâmetro do halo de hidrólise/Diâmetro da colônia) e posteriormente somados.

\subsubsection{Gel de Difusão de Esculina - EDGA}

As linhagens dos actinomicetos foram cultivadas em meio líquido (KASANA et al., 2008) com carboximetilcelulose (CMC) a $1 \%$ (p/v) como única fonte de carbono em tubos de $10 \mathrm{~mL}, \mathrm{pH} 5,0$, durante 5 dias sob agitação de $200 \mathrm{rpm}$ a $28^{\circ} \mathrm{C}$. A biomassa foi separada e o extrato foi aplicado no gel de difusão de esculina (EGDA), conforme descrito por Saqib e Whitney (2006) por 5 horas a $37^{\circ} \mathrm{C}$. Em seguida, a placa foi colocada sobre o gelo e mediu-se as zonas marrom-escuras formadas relativo à ação de $\beta$-glicosidase sobre esculina.

\subsection{Seleção das linhagens em frascos agitados}

Foram selecionados 12 linhagens de actinomicetos para a produção de hemicelulases e $\beta$-glicosidases. Essas linhagens foram previamente crescidas em ISP2 - ágar por três dias a 28 ${ }^{\circ} \mathrm{C}$. Posteriormente, um disco de $0,5 \mathrm{~cm}$ de diâmetro foi removido e transferido para Erlenmeyer contendo $20 \mathrm{~mL}$ do meio escolhido na padronização e incubado por 144 horas a $28{ }^{\circ} \mathrm{C}$ e $200 \mathrm{rpm}$ (Shaker Innova New Brunswick Scientific, USA). A fonte de carbono utilizada nesta etapa, foi $10 \mathrm{~g} / \mathrm{L}$ de bagaço de cana de açúcar pré-tratado por explosão a vapor 
quente e deslignificado com $1 \%(\mathrm{p} / \mathrm{v})$ de $\mathrm{NaOH}$ (BED) como descrito por Delabona et al., (2012) e farelo de soja (FS) na proporção mássica de 3:1. Amostras foram coletadas para determinação das atividades enzimáticas e concentração de proteína totais.

\subsubsection{Dosagem das atividades enzimáticas}

A quantificação das atividades enzimáticas, foram expressas em unidades internacionais (IU), que é igual a 1umol/ min. $\mathrm{mL}$ de substrato liberado na reação. A atividade de papel filtro (FPase) foi medida através do método descrito por Xiao et al., (2004). Os polissacarídeos de Xilana e Pectina foram utilizados a 0,5\% (p/v) por 10 minutos e para CMC foi utilizado a $1 \%(\mathrm{p} / \mathrm{v})$ por 30 minutos. A atividade enzimática foi determinada pela quantidade de açúcar redutor liberado a partir dos diferentes substratos pelo método de DNS (MILLER, 1959), utilizou-se glicose, xilose ou ácido galacturônico como padrão, as reações foram conduzidas adicionando $40 \mathrm{uL}$ de tampão fosfato $\mathrm{pH} 7,0(50 \mathrm{mM}), 10 \mathrm{uL}$ do sobrenadante e $50 \mathrm{uL}$ da solução do polissacarídeo. Incubou-se a $50{ }^{\circ} \mathrm{C}$ por 10 minutos, depois desse período acrescentou-se o DNS e incubou-se por mais 5 minutos a $95{ }^{\circ} \mathrm{C}$, após, as reações foram levadas a um banho de gelo fundente por 10 minutos e tiveram a absorbância lida em $540 \mathrm{~nm}$ As atividades de $\beta$-glicosidase, $\beta$-xilosidase, $\beta$-manosidase, $\alpha$-Larabinofuranosidase e celobiohidrolase II foram medidas a partir dos resíduos de p-nitrofenol (pNP) correspondentes (Sigma-Aldrich, EUA). As reações foram conduzidas utilizando $10 \mu \mathrm{L}$ do sobrenadante diluído e $90 \mu \mathrm{L}$ do respectivo pNP (0,5 mM diluído em $50 \mathrm{mM}$ de tampão). As reações foram incubadas por 10 minutos e foram finalizadas pela adição de $100 \mu \mathrm{L}$ de Na2CO3 (1M). A absorbância foi determinada a $400 \mathrm{~nm}$ em leitor de placas Tecan Infinite ${ }^{\circledR}$ 200 (Männedorf, Suíça). Para todas as dosagens utilizou-se tampão fosfato pH 7,0 (50 mM) e todas as reações foram conduzidas a $50{ }^{\circ} \mathrm{C}$ com exceção da atividade de pectinase que foi determinada a $37^{\circ} \mathrm{C}$.

\subsection{Triagem molecular}

Todas as linhagens também passaram por uma triagem molecular com o objetivo de complementar a seleção em placas, para isso, sequências de xilanases, arabinofuranosidases, endoglicanases e $\beta$-glicosidases pertencentes a actinomicetos com genoma já anotado e depositado em banco de dados foram procuradas no GenBank e KEGG. As sequências 
encontradas foram alinhadas utilizando o programa MEGA 5.1 e a partir de regiões conservadas das sequências alinhadas, iniciadores para as enzimas de interesse foram desenhados e mandados sintetizar.

\subsubsection{Extração de DNA genômico}

Para a extração de DNA todas as linhagens foram crescidas em meio YEME (anexo B) por 2 dias a $28{ }^{\circ} \mathrm{C}$ e a extração foi realizada de acordo com o protocolo do kit de isolamento de DNA genômico de bactérias gram positivas e gram negativas - Wzard Genomic DNA Purification Kit (PROMEGA)

\subsubsection{Desenho dos oligonucleotídeos degenerados}

Para a triagem molecular, foi preciso uma busca nos bancos de dados como o GenBank e KEGG referentes as sequências de aminoácidos e nucleotídeos das enzimas investigadas pertencentes ao grupo dos actinomicetos. As sequências encontradas foram alinhadas utilizando o programa MEGA 5.10 para análise de regiões conservadas de aminoácidos para a construção de iniciadores degenerados que pudessem abranger sequências de diferentes linhagens. Abaixo, segue a Tabela (Tabela 1) contendo a sequência de cada oligonucleotídeo, indicando também a orientação dos mesmos.

Tabela 1 - Sequências dos oligonucleotídeos utilizados

\begin{tabular}{lll}
\hline Nome & Orientação & Sequência \\
\hline B-glicosidase & Foward & 5'-ACSCTCTACCACTGGGACCT \\
& Reverse & 5'- AAGTTGTCSAKCAGSGACCA \\
Endoglicanase & Foward & 5'- TTCCACGAGGAGCGSTACGA \\
& Reverse & 5'- TTCGGGCCGCCCTTGCA \\
Arabinofuranosidase & Foward & 5'- AMGGCCAACGGCACRGMG \\
& Reverse & 5'- CTSCCGGTGAACAGCGSC \\
Xilanase & Forward & 5'- TGGGCGGTRCAGAACGGCAA \\
& Reverse & \\
\end{tabular}

$\mathrm{S}=\mathrm{G}$ ou $\mathrm{C} ; \mathrm{K}=\mathrm{G}$ ou $\mathrm{T} ; \mathrm{M}=\mathrm{A}$ ou $\mathrm{C} ; \mathrm{R}=\mathrm{A}$ ou $\mathrm{G} ; \mathrm{Y}=\mathrm{C}$ ou $\mathrm{T}$ 


\subsubsection{Reação em cadeia da Polimerase}

Uma vez os iniciadores desenhados e sintetizados, deu-se início as Reações em cadeia da Polimerase. O programa utilizado para a reação em cadeia da Polimerase (PCR) consistiu de 30 ciclos, onde a primeira temperatura utilizada foi de $95{ }^{\circ} \mathrm{C}$ por 1 minuto para a desnaturação, 1 ciclo, seguido de $94{ }^{\circ} \mathrm{C}$ por 2 minutos e a temperatura de anelamento variou de acordo com cada par de iniciadores, contudo, o tempo utilizado foi de 1 minuto e 30, para todos os pares de oligonucléotideos, para a extensão a temperatura utilizada foi de $72{ }^{\circ} \mathrm{C}$ por 1 minuto e após o término dos ciclos uma extensão final de $72{ }^{\circ} \mathrm{C}$ por 2 minutos foi realizada. É importante ressaltar que dependendo de cada par de iniciadores o programa sofreu variações.

Testes de padronização das reações fizeram-se necessários para a determinação da temperatura "ótima" para cada par de iniciadores. As concentrações dos reagentes seguiram as instruções do fabricante (Fermentas).

\subsubsection{Eletroforese em gel de agarose $(0,8 \%)$}

Os produtos dos PCR foram verificados por meio de gel de agarose 0,8\%, para confirmação de tamanho dos fragmentos. Foi realizada a corrida eletroforética empregando tampão TAE 1\%, com corrente de 90-100 V por 50-60 minutos. Para visualização das bandas o gel foi colocado em banho com brometo de etídeo $(0,5 \mu \mathrm{g} / \mathrm{mL})$ por 15 minutos. Após o banho com brometo de etídeo, o gel de agarose foi visualizado em luz UV. Cada fragmento apresentado foi cortado com auxílio de lâminas de bisturi e posteriormente purificados.

\subsubsection{Purificação dos fragmentos e Sequenciamento}

Os amplicons gerados por PCR com os iniciadores das sequências das enzimas (Xilanase, endoglicanase, beta-glucosidade e arabinofuranosidase), foram purificados com o kit GFX PCR DNA (GE Healthcare, U.K.) e sequenciados junto ao Centro de Estudo do Genoma Humano - USP, no sequenciador automático ABI 3130. As análises dos produtos sequenciados foram realizados utilizando o software BLASTn, disponível no banco de dados do NCBI (National Center for Biotechnology Information). Dessa forma, permitindo a confirmação do produto de PCR obtido e, consequentemente, a identificação de sequências homólogas presentes em diferentes micro-organismos. 


\subsection{4 Árvores filogenéticas}

As árvores filogenéticas foram construídas com base nas sequências das amostras estudadas e por meio de comparações com o banco de dados. Para a realização das árvores filogenéticas, o programa MEGA 5.10 foi utilizado, aplicando o método Neighbord-Joining, do modelo de Kimura (KIMURA, 1980).

\subsection{Identificação e breve caracterização das proteínas}

\subsubsection{Extrato protéico}

\subsubsection{Eletroforese em gel de poliacrilamida (SDS PAGE 12\%)}

A fim de iniciar a caracterização das proteínas relevantes para este trabalho foi realizado o gel de poliacrilamida - SDS-PAGE. Para isso, as linhagens foram crescidas no meio descrito por Nascimento et al., (2002) com as fontes de carbono sendo o CMC para as endoglicanases e betaglicosidases e a xilana de madeira de faia para xilanases e arabinofuranosidases. As linhagens selecionadas foram mantidas sob agitação de $200 \mathrm{rpm}$ por um período de 7 dias a $28{ }^{\circ} \mathrm{C}$ em Erlenmeyers de $500 \mathrm{~mL}$ com um volume de $100 \mathrm{~mL}$ para cada linhagem. Após esse período as amostras foram divididas em 2 tubos de $50 \mathrm{~mL}$ e centrifugadas para separação do pellet e sobrenadante. O sobrenadante foi congelado para a aplicação no gel. Para ter uma melhor concentração de proteínas no gel, as amostras foram concentradas até chegar a um volume de $25 \mathrm{~mL}$ por linhagem e a partir desse volume total foi realizada a precipitação de proteínas de acordo com o protocolo de precipitação de proteínas por TCA. O conteúdo total foi ressuspendido em $100 \mathrm{uL}$ de água destilada estéril, onde $80 \mathrm{uL}$ do produto final foi congelado em freezer $-20{ }^{\circ} \mathrm{C}$ para ensaios futuros e $20 \mathrm{uL}$ foi separado para aplicação no gel.

\subsubsection{Sequenciamento de proteínas}

Para o sequenciamento das bandas de possível interesse no gel de proteínas, foi realizado um estudo na literatura sobre o tamanho e a massa molecular das enzimas relacionadas neste estudo, dessa maneira, o gel corrido, foi cortado nas bandas de interesse e sequenciados pelo CEFAP (Centro de Facilidades para Pesquisa - ICB/ USP). As sequências foram utilizadas para identificação das enzimas de interesse. 
5.6.2 Caracterização da temperatura e pH das enzimas celulolíticas e hemicelulolíticas em linhagens de actinomicetos

A quantificação das atividades enzimáticas foram realizadas de maneira semelhante ao item de 5.4.1 de material e métodos e igualmente expressas em unidades internacionais (IU). As linhagens utilizadas foram cultivadas em meio descrito por Nascimento et al, (2002). As fontes de carbono utilizadas foram: xilana de madeira de faia e CMC. As linhagens foram cultivadas sob agitação de $200 \mathrm{rpm}$ à $28{ }^{\circ} \mathrm{C}$ por um período de 7 dias e amostras foram coletadas a cada 24 horas. A solução com o substrato CMC foi utilizada a $1 \%(\mathrm{p} / \mathrm{v})$ e para Xilana, foi utilizada a solução a $0,5 \%(\mathrm{p} / \mathrm{v})$. As atividades de $\beta$-glicosidase e $\alpha$-Larabinofuranosidase foram medidas a partir dos resíduos de p-nitrofenol (pNP) correspondentes (Sigma-Aldrich, EUA). As reações ocorrem igualmente a descrita no item 3.4.1 de material e métodos. Alterando somente as temperaturas as quais foram conduzidas as reações. Foram testadas quatro diferentes temperaturas $\left(40^{\circ} \mathrm{C}, 50^{\circ} \mathrm{C}, 60^{\circ} \mathrm{C}\right.$ e $\left.70^{\circ} \mathrm{C}\right)$. e para os testes com $\mathrm{pH}$, a faixa deste variou de 4,0 a 8,0 


\section{RESULTADOS}

\subsection{Recuperação e manutenção das linhagens de actinomicetos}

As linhagens de actinomicetos recuperadas da coleção de cultura do laboratório de Bioprodutos ICB - USP, tiveram um crescimento abundante após um período de 14 dias (período para uma ótima esporulação) a $28{ }^{\circ} \mathrm{C}$. As Figuras 3 e 4 mostram o crescimento de algumas linhagens estudadas nesse trabalho. É importante ressaltar que as placas contendo as bactérias semeadas, eram visualizadas diariamente para certificação de não contaminação.
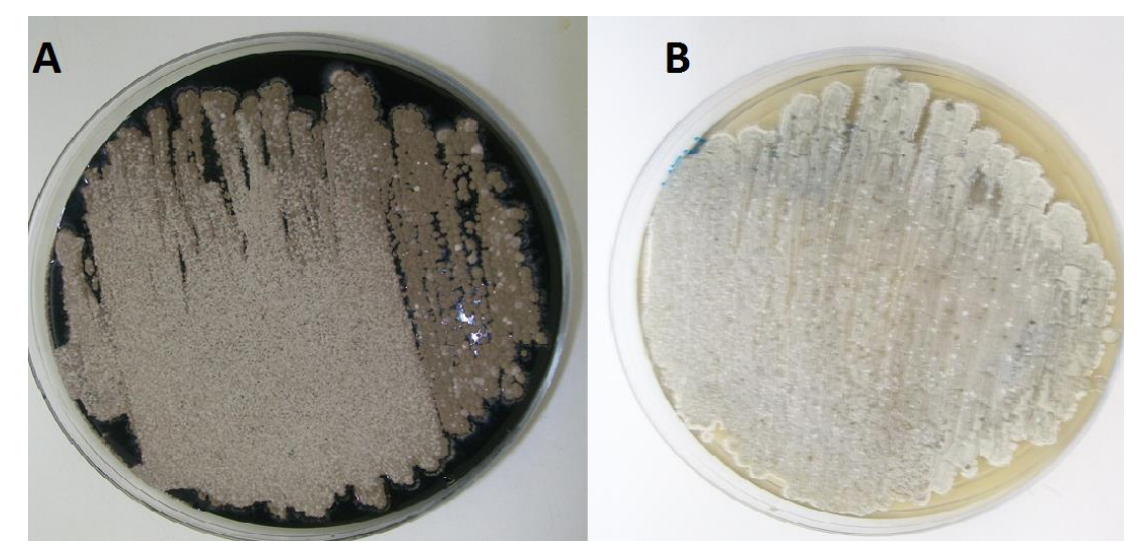

Figura 3 - Actinomicetos endofíticos crescidos em placas contendo o meio ISP2, onde A) linhagem G1P1 e B) A10.

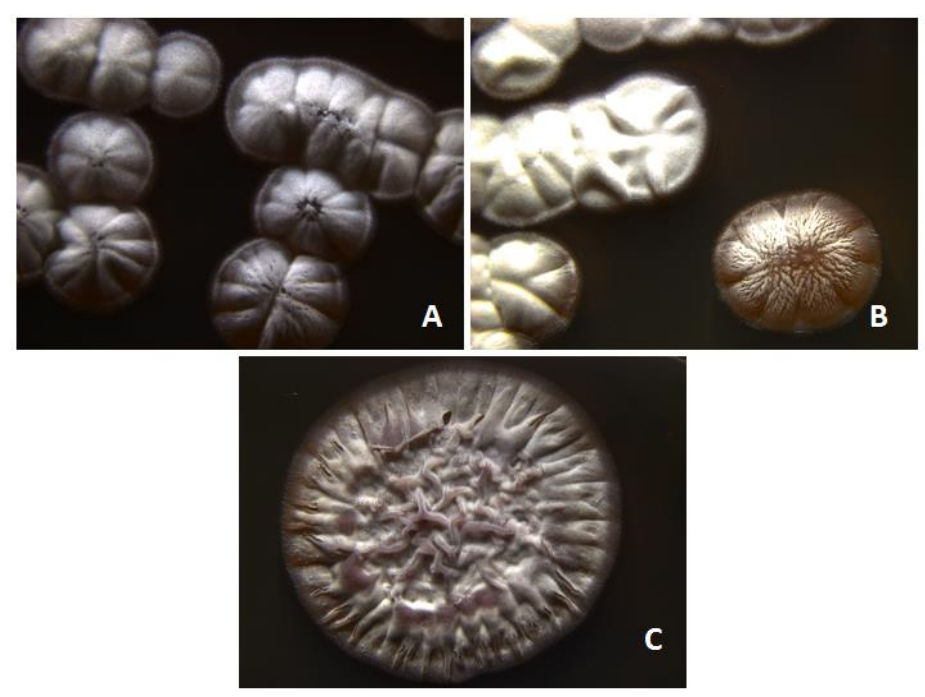

Figura 4 - A) Colônias da linhagem de Streptomyces olindensis isolada de solo e utilizada nesse trabalho por ser micro-organismo modelo do Laboratório de Bioprodutos - USP; B) aponta colônias isoladas com variações morfológicas e C) Características mais detalhada de colônia isolada. 


\subsection{Triagem das linhagens em meio sólido}

\subsubsection{Padronização de triagem em meio sólido}

Nesta etapa, o objetivo foi avaliar quais micro-organismos eram potencialmente bons produtores das enzimas procuradas e que seriam importantes para os ensaios futuros.

Os actinomicetos foram testados em três diferentes meios de cultura e com adição de diferentes fontes de carbono para cada enzima de interesse. Para a visualização dos resultados da seleção em placa, dois corantes foram utilizados e esse teste apresentou grande importância para avaliar qual desses corantes seria o mais eficiente e geraria resultados mais confiáveis. A hidrólise foi observada e medida pelo tamanho do halo de degradação, assim como descrito em material e métodos no item 5.3.1. As fontes de carbono estão descritas no mesmo item.

A primeira fonte de carbono testada foi o farelo de trigo. O meio com o farelo de trigo $(0,2 \%)$ apresentou problemas devido a sua grande granulosidade, além disso, o meio com farelo de trigo não foi bem corado com a solução de vermelho congo, já quando corado com solução de lugol o meio apresentou uma coloração muito escura, sem a possibilidade de visualização de halos, mesmo quando a concentração do corante foi reduzida. Com base nos fatos apresentados, a concentração de farelo de trigo foi reduzida de $0,2 \%$ para $0,05 \%$.

Ainda durante os testes de padronização e sob as novas condições para o uso de farelo de trigo $(0,05 \%)$, foi observado que o controle positivo apresentou halo de hidrólise quando corado com lugol, mas não apresentou quando corado com vermelho congo, o que indicaria um resultado falso positivo para as referidas enzimas procuradas no presente trabalho. No entanto, esses resultados podem indicar a presença de amido no ágar comercial. A Figura 5 mostra a formação de halos e do possível resultado falso positivo. 


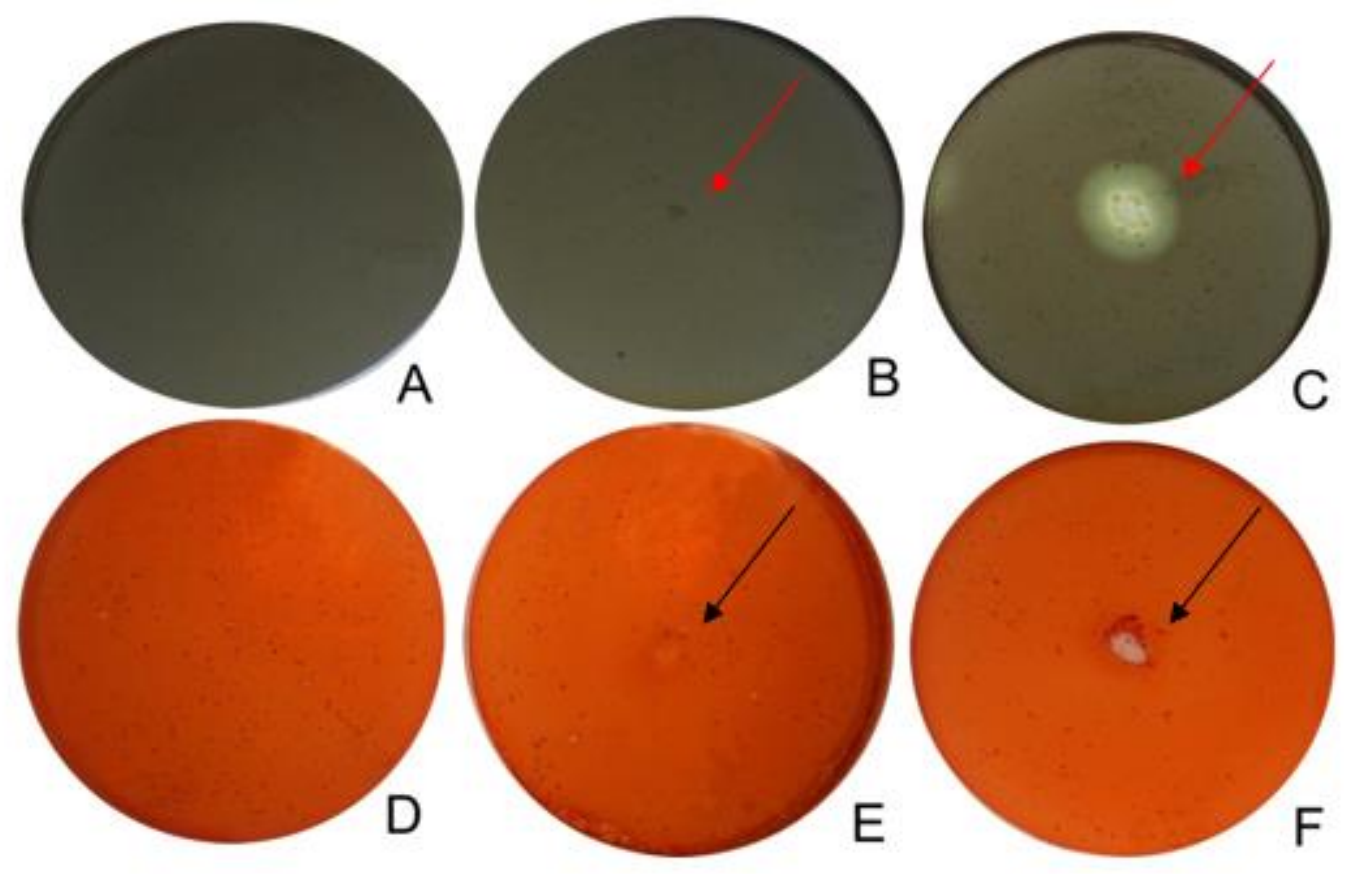

Figura 5 - Meio de farelo de trigo coradas com Lugol (A, B e C) e Vermelho Congo (D, E e F). Branco (A e D), E. coli ATCC25922 (B e E) e S. lividans TK21 (C e F). As setas em vermelho indicam a formação de colônias e visualização dos halos de hidrólise pela coloração do meio com lugol, as setas em preto mostram a coloração do meio pelo vermelho congo).

Desta forma, optou-se por não utilizar essa fonte de carbono no meio de seleção para as linhagens. Já os meios com o CMC, xilana e licor, quando corados com vermelho congo e lugol apresentaram halos bem definidos para os padrões positivos e ausência de halos para os padrões negativos (Figura 6). 


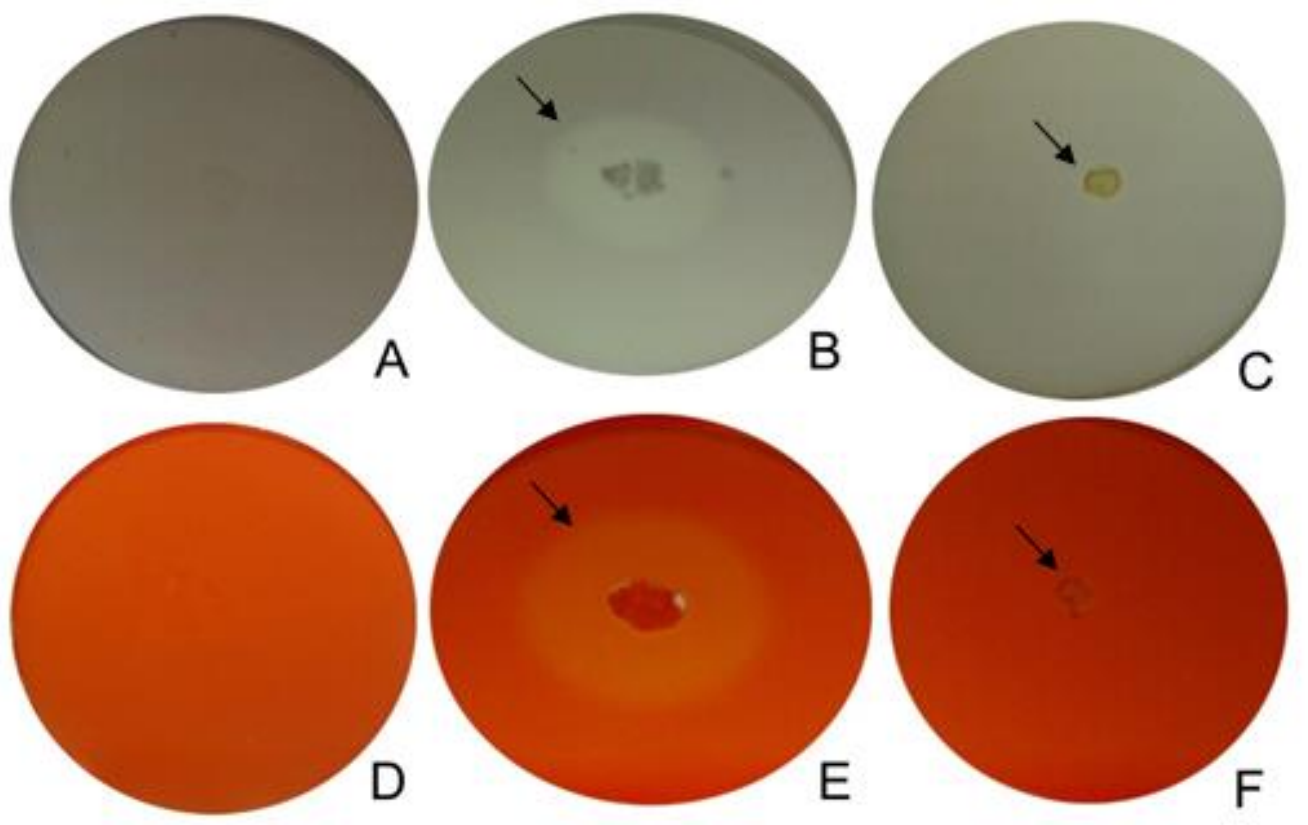

Figura 6 - Agar CMC coradas com Lugol (A, B e C) e Vermelho Congo (D, E e F). Branco (A e D), S. lividans TK21 (B e E) e Nocardia sp. A14 (C e F). As setas indicam a formação do halo em B e E e somente o crescimento em C e F.

Entretanto, com base na concepção de falsos positivos, as duas colorações foram testadas nos meios sem a adição de qualquer fonte de carbono. Os resultados mostraram que as placas que foram coradas com lugol apresentaram halos para os padrões positivos, porém não foram visualizados halos quando coradas com vermelho congo para as mesmas linhagens (Figura 7). 


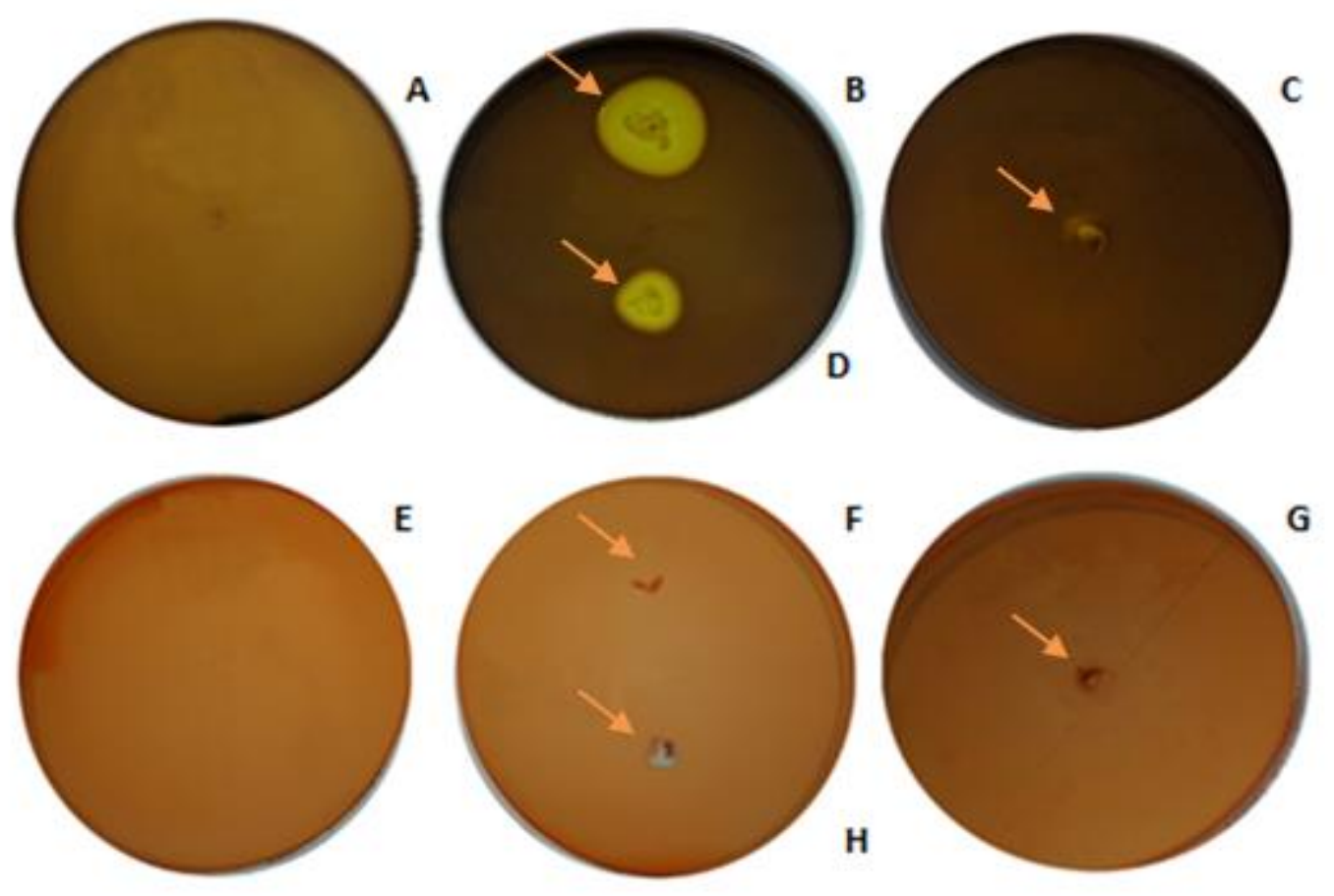

Figura 7 - Meio de seleção sem fonte de carbono coradas com Lugol (A, B, C e D) e Vermelho Congo (E, F, G e H). Branco (A e E), SoWT (B e F), S. lividans TK21 (D e H) e E. coli ATCC25922 (C e G), padrão negativo. As setas indicam a visualização de halos para o meio corado com lugol e a não formação de halos para o meio corado com vermelho congo.

Para resultados mais precisos optou-se por não utilizar a solução de lugol como o agente revelador, portanto, a solução de vermelho congo foi o corante selecionado para testes futuros. O meio de cultura que foi considerado o mais completo para a seleção das linhagens em meio sólido foi o descrito por Nascimento et. al., 2002, o mesmo usado na Tabela 2.

\subsubsection{Seleção das linhagens em meio sólido e Teste de difusão de Esculina (EDGA)}

Uma vez definidos o meio de cultura e o corante a serem utilizados nos experimentos, todas as linhagens foram então repicadas. A Tabela 2 mostra os resultados das atividades hidrolíticas para CMC, xilana e licor e do teste de EDGA.

Nota-se que ao utilizar o licor (resultado do tratamento endotérmico do bagaço da cana), grande parte das linhagens de actinomicetos não foi capaz de crescer usando este substrato como única fonte de carbono. Já para o uso de CMC e de xilana, a maioria das linhagens teve crescimento e foram capazes de produzir halos de hidrólise.

Para encontrar uma linhagem com bons índices de degradação das enzimas procuradas nesse trabalho, foi realizado o somatório dos índices de hidrólise (como mostrado no item 
3.3.1 de material e métodos). As linhagens em que a somatória dos índices obteve valor igual ou acima de 9,0, foram considerados importantes e encontram-se destacadas na Tabela 2. $\mathrm{O}$ valor considerado relevante foi determinado dado o maior valor entre os somatórios dos índices $(10,79)$. Aquelas linhagens que tiveram seus índices menores ou iguais a 1,00 foram considerados como produtores não eficientes de enzimas do sistema celulolítico e hemicelulolítico. No caso do teste de EDGA, a maioria das linhagens não apresentou um bom desempenho e aquelas que obtiveram resultados positivos seguiram para a quantificação das atividades enzimáticas, as linhagens selecionadas estão em destaque na Tabela 2.

Tabela 2 - Linhagens e seus índices de hidrólise para três substratos diferentes com posterior somatória e resultado do teste de EDGA.

\begin{tabular}{|c|c|c|c|c|c|c|c|c|}
\hline - & Linhagem & Identificação & Fonte & $\begin{array}{l}\text { Índice de } \\
\text { hidrolise } \\
\text { no Agar } \\
\text { CMC }\end{array}$ & $\begin{array}{l}\text { Índice de } \\
\text { hidrolise } \\
\text { no Agar } \\
\text { Licor }\end{array}$ & $\begin{array}{l}\text { Índice de } \\
\text { hidrolise } \\
\text { no Agar } \\
\text { Xilana }\end{array}$ & $\begin{array}{l}\text { Somatória } \\
\text { dos } \\
\text { índices }\end{array}$ & $\begin{array}{l}\text { Média dos } \\
\text { halos em } \\
\text { EGDA } \\
(\mathrm{mm})\end{array}$ \\
\hline 1 & NRRL 2272 & Streptomyces galileus & Solo & 2,04 & 4,80 & 3,37 & 10,21 & + \\
\hline 3 & JR1 & Streptomyce globisporus & Catharanthus roseus & 2,67 & 4,22 & 3,21 & 10,10 & + \\
\hline 4 & A21 & Streptomyces sp. & Citrus sinensis & 1,94 & 3,60 & 3,2 & 8,74 & + \\
\hline 7 & B6P4 & Streptomyces sp. & $\begin{array}{l}\text { Saccharum } \\
\text { officinarum }\end{array}$ & 2,55 & 2,64 & 3,83 & 9,02 & - \\
\hline 8 & $\mathrm{H} 4 \mathrm{P} 4$ & Streptomyces sp. & $\begin{array}{l}\text { Saccharum } \\
\text { officinarum }\end{array}$ & 3,67 & 2,31 & 3,83 & 9,81 & - \\
\hline 9 & A10 & Streptomyces sampsonii & Citrus reticulata & 2,05 & 3,40 & 2,73 & 8,18 & - \\
\hline 10 & A82 & $\begin{array}{l}\text { Streptomyces } \\
\text { pseudogriseolus }\end{array}$ & $\begin{array}{l}\text { Saccharum } \\
\text { officinarum }\end{array}$ & 3,08 & 3,67 & 2,31 & 9,06 & - \\
\hline 13 & G1P1 & S. pseudogriseolus & $\begin{array}{l}\text { Saccharum } \\
\text { officinarum }\end{array}$ & 3,45 & 1,88 & 2,77 & 8,10 & - \\
\hline 14 & $\mathrm{~A} 01$ & Streptomyces sp. & Citrus reticulata & 2,31 & 2,00 & 2,56 & 6,87 & - \\
\hline 15 & - & Streptomyces capoamus & Solo & 5,00 & 2,00 & 2,40 & 9,40 & - \\
\hline 16 & JR3 & $\begin{array}{l}\text { Streptomyces } \\
\text { roseochromogenus }\end{array}$ & Catharanthus roseus & 2,63 & 1,50 & 2,80 & 6,93 & 12 \\
\hline
\end{tabular}




\begin{tabular}{|c|c|c|c|c|c|c|c|c|}
\hline 17 & SoWT & Streptomyces olindenses & Solo & 2,10 & 2,00 & 2,22 & 6,32 & ${ }^{c}+$ \\
\hline 18 & ATCC 31267 & Streptomyces avermitilis & Solo & 2,13 & 1,20 & 3,00 & 6,33 & - \\
\hline 19 & A07 & Nocardiopsis sp. & Citurs sinensis & 1,45 & ${ }^{\mathrm{b}} 1,00$ & 3,13 & 4,58 & - \\
\hline 20 & G10P4 & Streptomyces macrosporeus & $\begin{array}{l}\text { Saccharum } \\
\text { officinarum }\end{array}$ & 2,09 & 1,40 & 2,10 & 5,59 & - \\
\hline 21 & A28 & Streptomyces sp. & Citurs sinensis & 1,36 & 2,44 & 1,00 & 4,80 & - \\
\hline 22 & A18 & Streptomyces sp. & Citurs sinensis & 1,94 & ${ }^{\mathrm{a}} 0,00$ & 3,25 & 5,19 & - \\
\hline 23 & A03 & Nocardiopsis sp. & Citrus reticulata & 1,56 & 0,00 & 3,00 & 4,56 & - \\
\hline 24 & $\mathrm{~A} 12 \mathrm{P} 2$ & Streptomyces sp. & $\begin{array}{l}\text { Saccharum } \\
\text { officinarum }\end{array}$ & 2,86 & 0,00 & 2,93 & 5,79 & - \\
\hline 25 & TK21 & Streptomyces lividans & Solo & 2,59 & 0,00 & 2,86 & 5,45 & + \\
\hline 26 & DSM46458 & Streptomyces chartresuts & Solo & 1,43 & 1,60 & 1,00 & 4,03 & - \\
\hline 27 & ССТ2398 & Streptomyces rimosus & Solo & 2,37 & 1,33 & 1,00 & 4,70 & - \\
\hline 28 & A04 & Nocardiopsis sp. & Citrus reticulata & 4,00 & 0,00 & 2,27 & 6,27 & - \\
\hline 29 & A30 & Streptomyces verne & Citurs sinensis & 1,80 & 0,00 & 2,05 & 3,85 & - \\
\hline 30 & A26 & Streptomyces sp. & Citurs sinensis & 1,00 & 1,00 & 1,00 & 3,00 & + \\
\hline 31 & A08 & Streptomyces sp. & Citrus reticulata & 1,00 & 1,00 & 1,00 & 3,00 & - \\
\hline 32 & A09 & Streptomyces sp. & Citurs sinensis & 1,00 & 1,00 & 1,00 & 3,00 & - \\
\hline 33 & A11 & Nocardiopsis sp. & Citurs sinensis & 3,70 & 0,00 & 1,56 & 5,26 & - \\
\hline 34 & A22 & Nocardiopsis sp. & Citurs sinensis & 1,88 & 0,00 & 1,55 & 3,43 & 14,5 \\
\hline 35 & A14 & Nocardiopsis sp. & Citurs sinensis & 1,00 & 0,00 & 1,00 & 2,00 & + \\
\hline 36 & A16 & Nocardiopsis sp. & Citurs sinensis & 1,00 & 0,00 & 1,00 & 2,00 & - \\
\hline 37 & A23 & Streptomyces sp. & Citurs sinensis & 1,00 & 1,00 & 1,00 & 3,00 & - \\
\hline 38 & A32 & Streptomyces sp. & Citurs sinensis & 1,00 & 0,00 & 1,00 & 2,00 & - \\
\hline 39 & АЗP1 & Streptomyces albus & $\begin{array}{l}\text { Saccharum } \\
\text { officinarum }\end{array}$ & 1,00 & 0,00 & 1,00 & 2,00 & - \\
\hline 40 & A4P1 & Streptomyces pulveraceus & $\begin{array}{l}\text { Saccharum } \\
\text { officinarum }\end{array}$ & 1,00 & 0,00 & 1,00 & 2,00 & - \\
\hline 41 & F7P4 & Streptomyces akiyoshiensis & $\begin{array}{l}\text { Saccharum } \\
\text { officinarum }\end{array}$ & 3,71 & 0,00 & 1,00 & 4,71 & - \\
\hline 42 & H4P3 & Streptomyces tsukiyonensis & $\begin{array}{l}\text { Saccharum } \\
\text { officinarum }\end{array}$ & 1,15 & 0,00 & 1,00 & 2,15 & - \\
\hline
\end{tabular}

Em amarelo estão as linhagens que se detacaram nos testes. 


\subsubsection{Seleção dos actinomicetos em frascos agitados}

\subsubsection{Dosagem das atividades enzimáticas}

De acordo com os testes feitos em placas, 12 linhagens (destaque na Tabela 3) foram selecionadas para o ensaio com meio BED+FS, em frascos agitados, e tiveram suas atividades enzimáticas mensuradas para determinadas enzimas, a linhagem de Streptomyces lividans, serviu como controle, já que tem atividade descrita para enzimas celulolíticas. As medidas das atividades enzimáticas ocorreram após 48 e 96 horas de incubação. Baixas atividades de $\beta$ glicosidase, FPase, CMCase e pectinase foram detectadas, como mostra a Figura 8. A baixa produção de $\beta$-glicosidase também foi visualizada anteriormente em testes feitos em placas pelo método de EDGA. Entre as linhagens totais testadas, somente 5 apresentaram atividade para $\beta$-glicosidase, entretanto, nos testes dos frascos agitados as linhagens selecionadas ficaram abaixo do limite de detecção dessa enzima pelo método de p-nitrofenol. Duas linhagens JR1 e JR3 apresentaram resultado positivo para a produção de xilanases, onde os picos puderam ser detectados em 48 horas. Em 96 horas, a linhagem E4.1 apresentou um aumento na atividade de xilanase, indicando que essa linhagem pode ser promissória para a produção de xilanase, ainda que outras linhagens tiveram suas atividades acima e em período de incubação menor. 

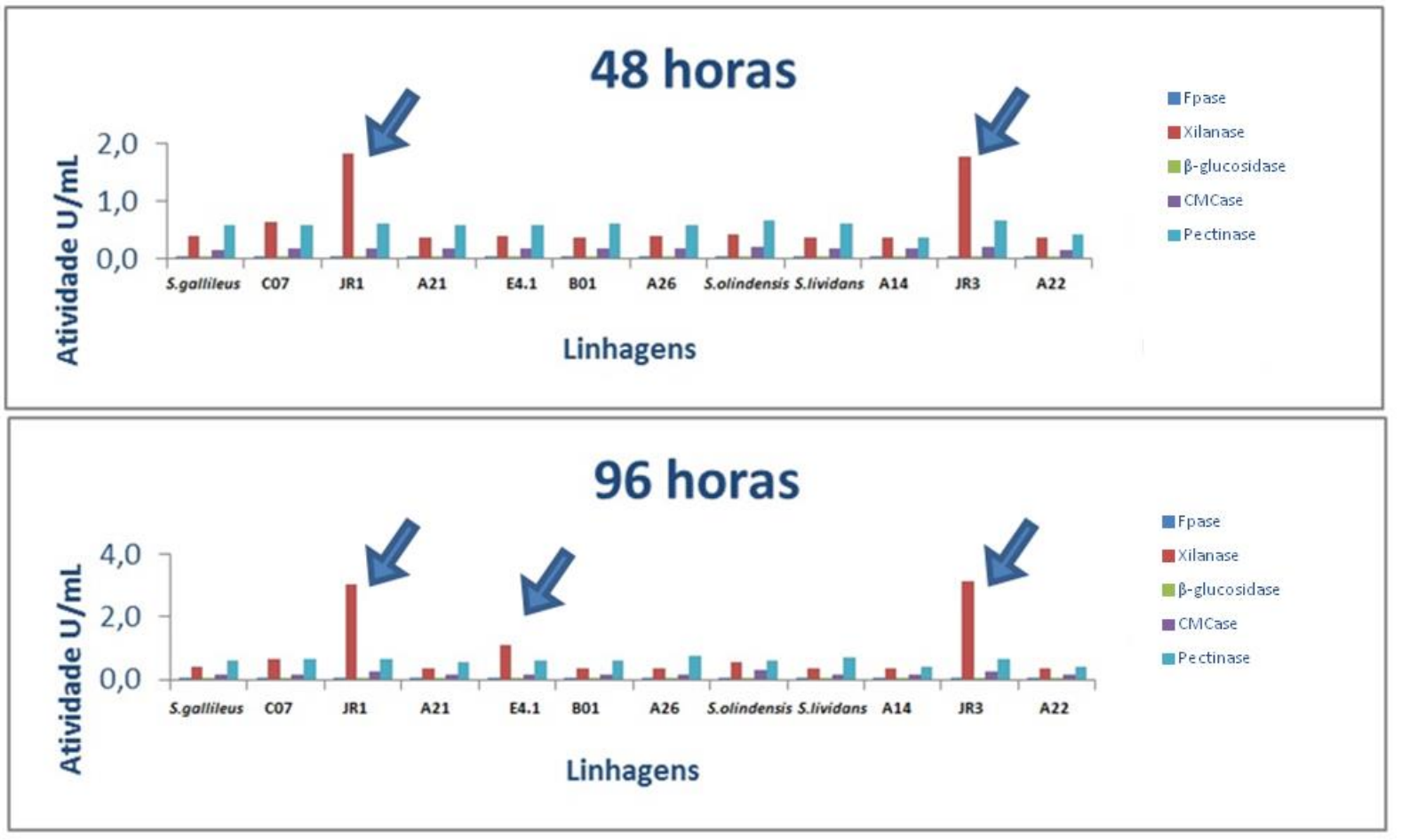

Figura 8. Atividades enzimáticas das 12 linhagens bacterianas crescidas em frascos agitados com BED+FS (3:1) com 48 e $96 \mathrm{~h}$.

\subsection{Triagem com primers degenerados para detecção dos possíveis genes que codificam para enzimas celulolíticas e hemicelulolíticas.}

Adicionalmente a seleção por meios de cultura e pela detecção de picos de atividade enzimática pelo método de frascos agitados fez-se a triagem molecular com as 42 linhagens que deram início ao trabalho a fim de verificar a presença dos genes das enzimas.

\subsubsection{Iniciadores degenerados e reação em cadeia da polimerase (PCR)}

Os oligonucleotídeos degenerados desenhados para cada uma das quatro enzimas de interesse (Endoglicanase, $\beta$-glicosidase, xilanase e arabinofuranosidase), foram preliminarmente testados com Streptomyces coelicolor e Streptomyces avermitilis, pois essas cepas já possuem seus genomas anotados e depositados nos bancos de dados com sequências das referidas enzimas, igualmente foram utilizadas para verificar a qualidade dos iniciadores. Foi necessária uma padronização das reações e se examino a melhor temperatura de anelamento dos iniciadores por meio de sucessivos PCRs para cada enzima procurada como aponta a Tabela 3. 
Tabela 3 - Padronização da temperatura de anelamento dos oligonucleotídeos usados na triagem molecular

\begin{tabular}{llll}
\hline Nome & Orientação & $\begin{array}{l}\text { TM específica de cada primer em } \\
\text { of }\end{array}$ & $\begin{array}{l}\text { TM usada nas reações em } \\
\text { oC }\end{array}$ \\
\hline B-glicosidase & Forrward & 54.8 & 53.0 \\
& Reverse & 55.3 & \\
Endoglicanase & Foward & 60.0 & 60.0 \\
Arabinofuranosidase & Reverse & 65.1 & 62.0 \\
& Forward & 62.0 & \\
Xilanase & Reverse & 62.1 & 63.5 \\
& Forward & 66.7 & \\
\hline
\end{tabular}

Os resultados mostram que de 42 linhagens testadas, 51,17\% das amostras foram positivas para $\beta$-glicosidase, $72 \%$ tiveram amplicons com iniciadores para endoglicanse, $84 \%$ para arabinofuranosidase e $80 \%$ das amostras foram positivas quando com iniciadores de xilanse. Com os resultados obtidos por meio das reações do PCR, um grupo menor de oito actinomicetos foi selecionado e deu continuidade aos estudos. As oito linhagens selecionadas apresentaram amplificação para mais de um par de iniciadores. Novos PCRs foram realizados com o objetivo dos amplicons gerados serem seqüenciados. Dessa maneira, foi possível averiguar se os fragmentos vistos no gel eram das referidas enzimas, então a identidade pôde ser comparada com o banco de dados e confirmada.

\subsection{2 Árvores filogenéticas dos genes das enzimas celulolíticas e hemicelulolíticas}

A partir da comparação com as sequências do banco de dados do NCBI, árvores filogenéticas foram construídas para cada uma das enzimas, como mostram as Figuras 9 a 12. 


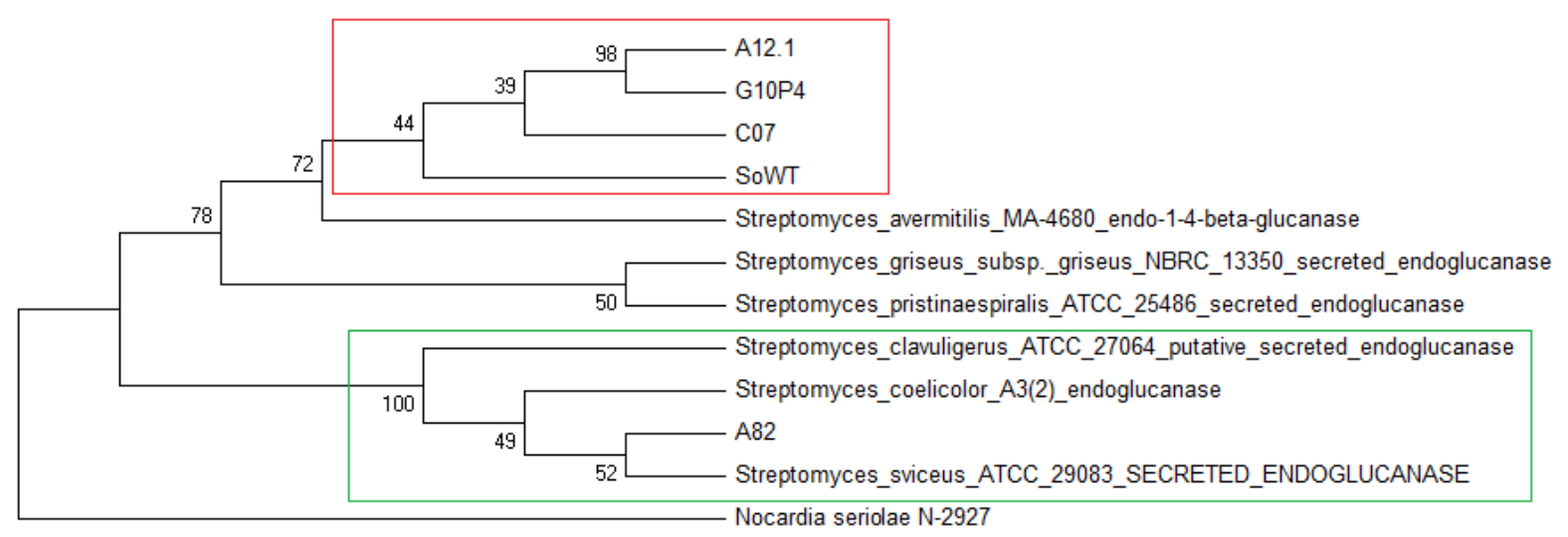

Figura 9 - Árvore filogenética do gene que codifica para endoglicanase, baseada nas sequências das amostras estudadas e das amostras do banco de dados do NCBI. O quadro em vermelho mostra que a maioria das linhagens testadas no trabalho está formando um grupo distinto das demais amostras, enquanto o quadro em verde mostra que a linhagem A82, está em outro grupo.

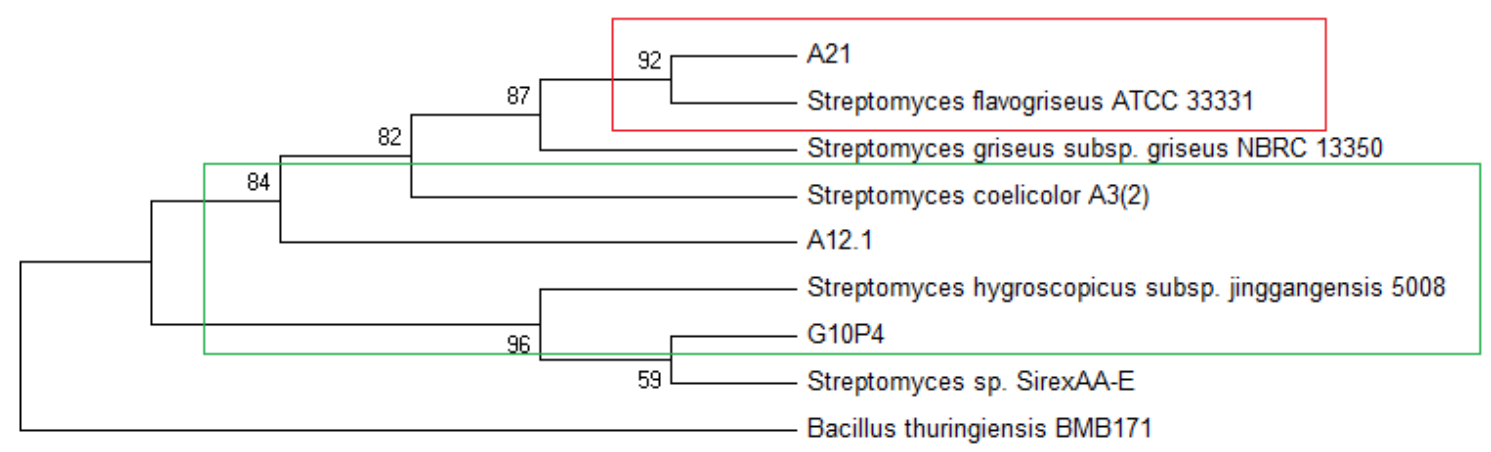

Figura 10 - Árvore filogenética do gene que codifica para $\beta$-glicosidases, baseada nas sequências das amostras estudadas e das amostras do banco de dados do NCBI. O quadro em vermelho está mostrando que a linhagem A21 tem maior identidade com a Streptomyces flavogriseus ATCC 33331, enquanto as linhagens que se encontram no quadro em verde são mais similares com Streptomyces coelicolor A3(2) 


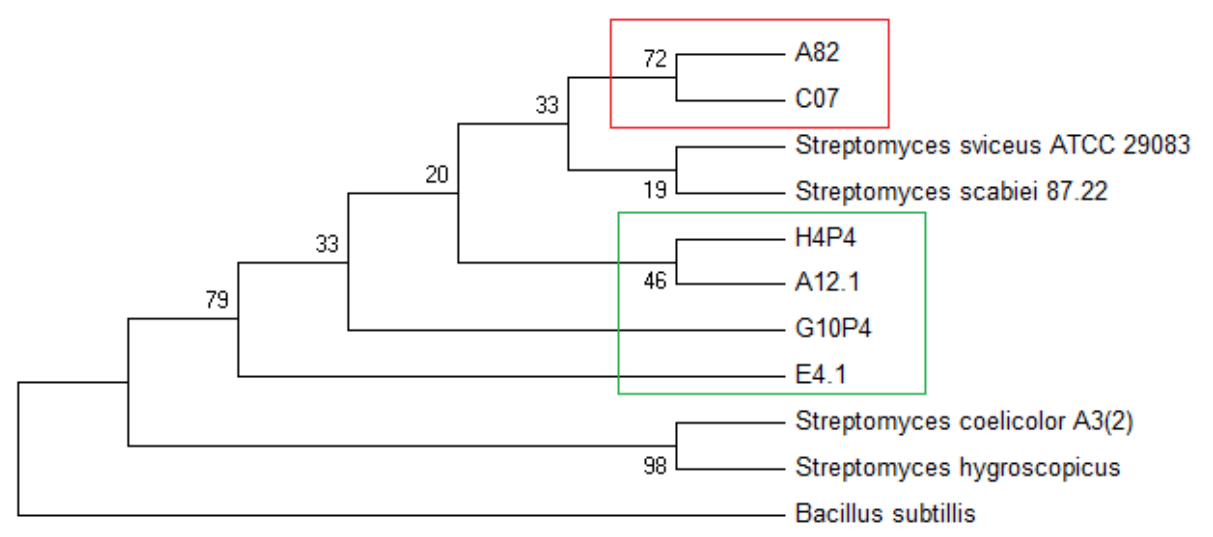

Figura 11 - Árvore filogenética do gene que codifica para xilanase, baseada nas sequências das amostras estudadas e das amostras de banco de dados do NCBI. Observam-se valores de identidade entre as amostras consideravelmente baixos. *As sequências estudadas são de xylanase A.

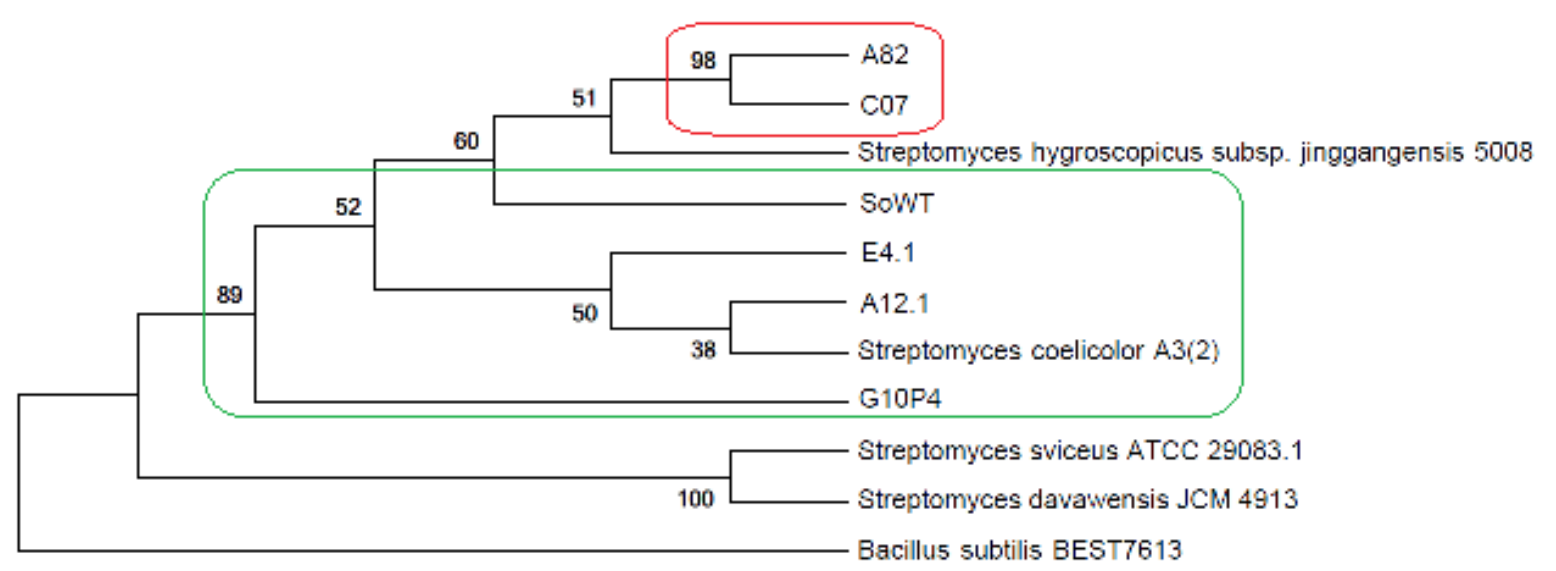

Figura 12 - Árvore filogenética do gene que codifica para arabinofuranosidase baseada nas sequências das amostras estudadas e das amostras de banco de dados do NCBI. Destacados pelo quadro em vermelho estão duas linhagens com alto valor de identidade. No quadro em verde aparecem as linhagens com menores identidades e em grupo distinto.

Na Figura 9, o grupo das bactérias endofíticas estão praticamente todas agrupadas, ou seja, a identidade entre elas é maior do que com as sequências encontradas no banco de dados, porém, a linhagem A82, isolada de rizosfera de cana de açúcar, está em um grupo com uma identidade de $90 \%$ em comparação com linhagens do banco de dado. Já na Figura 10, o sequenciamento dos amplicons gerados, não permitiu chegar a uma conclusão. No entanto, as linhagens apresentadas na árvore filogenética exibiam um bom espectro com resultados bem definidos. É possível observar ainda na Figura 10, que a linhagem A21 tem uma identidade bastante alta com Streptomyces flavogriseus ATCC 33331 do banco de dados do NCBI, 
indicando que esses podem possuir sequências iguais e as linhagens mais distintas são A12.1 e G10P4.

Os iniciadores de xilanase foram os que geraram os melhores amplicons e os resultados do sequenciamento foram os mais eficientes, com exceção de apenas duas linhagens, Streptomyces olindensis e A21. Nessa árvore (Figura 11) observa-se que as linhagens são na maioria isoladas de rizosfera de cana de açúcar, uma de fonte desconhecida e uma isolado de cacaueiro. Foram gerados três grupos com as linhagens deste trabalho, sendo a mais distinta das outras a linhagem E4.1. Por fim, o resultado mostrado na Figura 12, aponta que as linhagens A82 e C07 tem uma identidade de 98\%, o que significa um valor relevante em comparação com outras linhagens. E as linhagens E4.1 e A12.1 apontam para uma arabinofuranosidase diferente das descritas nos bancos de dados.

Outro dado que pôde ser observado é que mesmo analisando-se as fontes das quais as bactérias foram isoladas, não houve uma correlação imediata com as identidades e agrupamentos.

Para a construção das árvores filogenéticas, grupos externos foram adicionados. Em 9, foi utilizado como grupo externo uma Nocardia sp. Essa foi escolhida por ser gram positiva, aeróbica obrigatória, não produz esporos e faz parte da mesma ordem (Actinomycetales). Já nas árvores das Figuras 10, 11 e 12, o grupo externo foi constituído por Bacillus sp. que é um micro-organismo bastante estudado, é uma bactéria gram-positiva, com capacidade de entrar em estágio de endósporo e alguns estudos já relacionam a capacidade de Bacillus subtilis de atuar como bioproduto eficiente em relação ao controle de doenças ou crescimento de plantas (FILHO, 2010). Bacillus sp. foi utilizado principalmente por não terem sido encontradas sequências de $\beta$-glicosidase, xilanase e arabinofuranosidase em Nocardia.

\subsection{Caracterização das enzimas por meio da medição das atividades sob influência de diferentes temperaturas e pHs utilizando o extrato proteico}

Para a breve caracterização das enzimas, o extrato proteico foi analisado quanto a diferentes temperaturas e diferentes pHs. Nessa fase do trabalho, foram utilizadas somente quatro linhagens que se destacaram na maioria dos ensaios anteriores. Quatro temperaturas e quatro $\mathrm{pHs}$ foram analisados e foram escolhidos por serem os mais encontrados na literatura e em processos industriais. 
6.4.1 Influência da temperatura e pH na atividade das enzimas celulolíticas $e$ hemicelulolíticas em linhagens de actinomicetos.

Com a bioprospecção realizada sob algumas condições, foi iniciada uma caracterização das enzimas. As amostras crescidas em meio com um indutor (CMC e xilana) tiveram amostras coletadas a cada 24 horas, centrifugadas e o sobrenadante armazenado em $20^{\circ} \mathrm{C}$. Ao término do período de 7 dias ou 168 horas de crescimento e indução, pelo método de dosagem de atividade enzimática por açúcar redutor ou por resíduos de p-nitrofenol, quatro temperaturas $\left(40^{\circ} \mathrm{C}, 50^{\circ} \mathrm{C}, 60^{\circ} \mathrm{C}\right.$ e $\left.70^{\circ} \mathrm{C}\right)$ e quatro pHs $(4,0 ; 6,0 ; 7,0$ e 8,0$)$ foram testados.

\subsubsection{Influência da temperatura na atividades de xilanase}

As Figuras 13 a 16, mostram como cada linhagem selecionada reagiram sob cada temperatura testada com a indução por xilana.

\section{Linhagem E4.1}

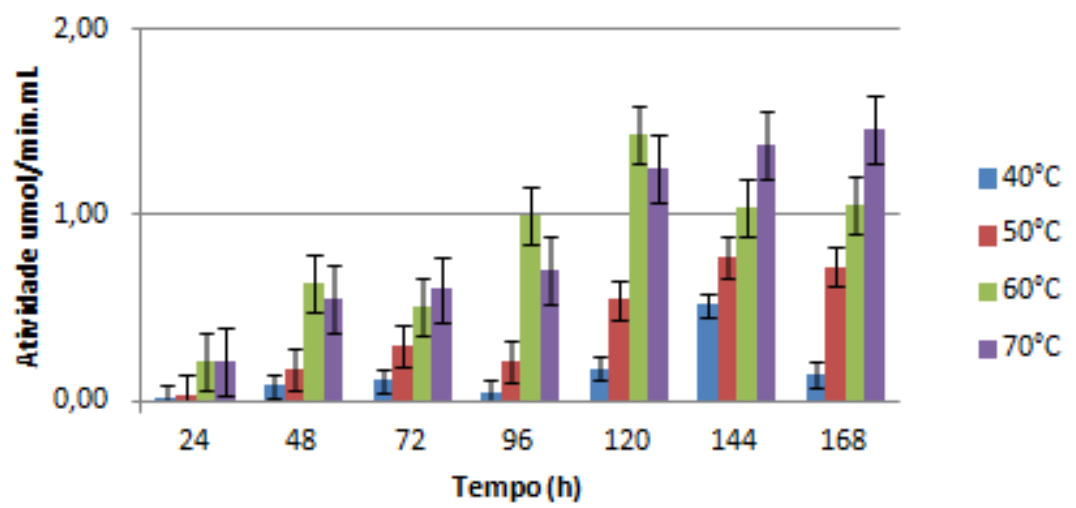

Figura 13 - Dosagem de xilanase para a linhagem E4.1 sob diferentes temperaturas. Em azul, $40{ }^{\circ} \mathrm{C}$, em vermelho, $50{ }^{\circ} \mathrm{C}$, em verde, $60{ }^{\circ} \mathrm{C}$ e em roxo a temperatura de $70{ }^{\circ} \mathrm{C}$. 


\section{Linhagem SoWT}

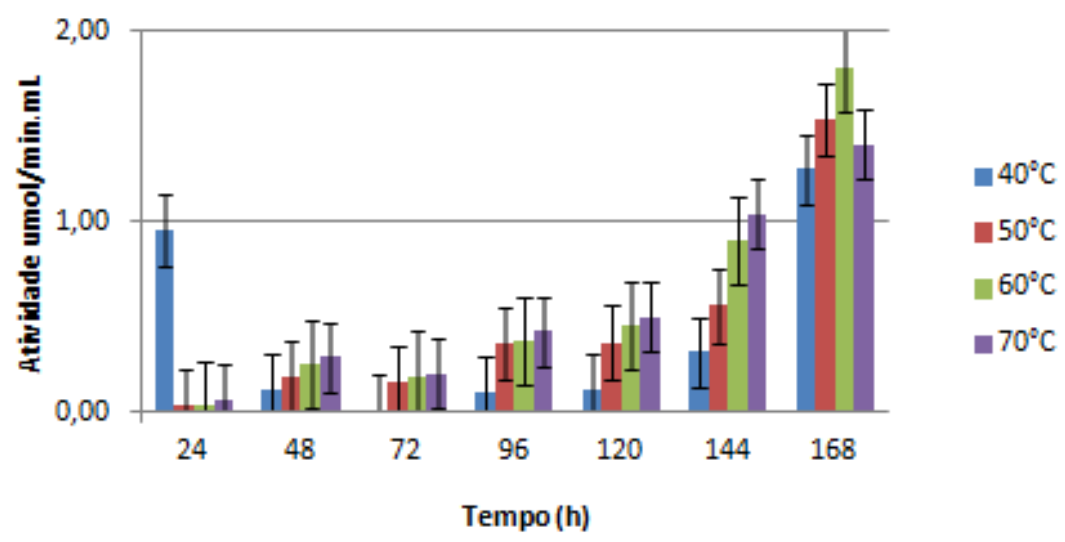

Figura 14 - Dosagem de xilanase para a linhagem Streptomyces olindensis sob diferentes temperaturas. Em azul, $40{ }^{\circ} \mathrm{C}$, em vermelho, $50^{\circ} \mathrm{C}$, em verde, $60{ }^{\circ} \mathrm{C}$ e em roxo a temperatura de $70{ }^{\circ} \mathrm{C}$.

\section{Linhagem C07}

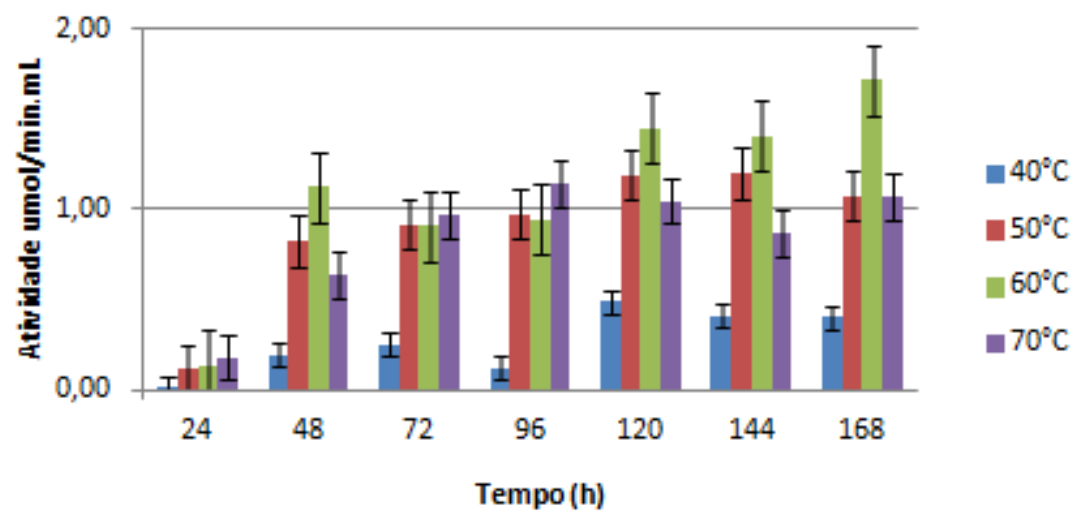

Figura 15 - Dosagem de xilanase para a linhagem C07 sob diferentes temperaturas. Em azul, $40{ }^{\circ} \mathrm{C}$, em vermelho, $50{ }^{\circ} \mathrm{C}$, em verde, $60{ }^{\circ} \mathrm{C}$ e em roxo a temperatura de $70{ }^{\circ} \mathrm{C}$. 


\section{Linhagem A82}

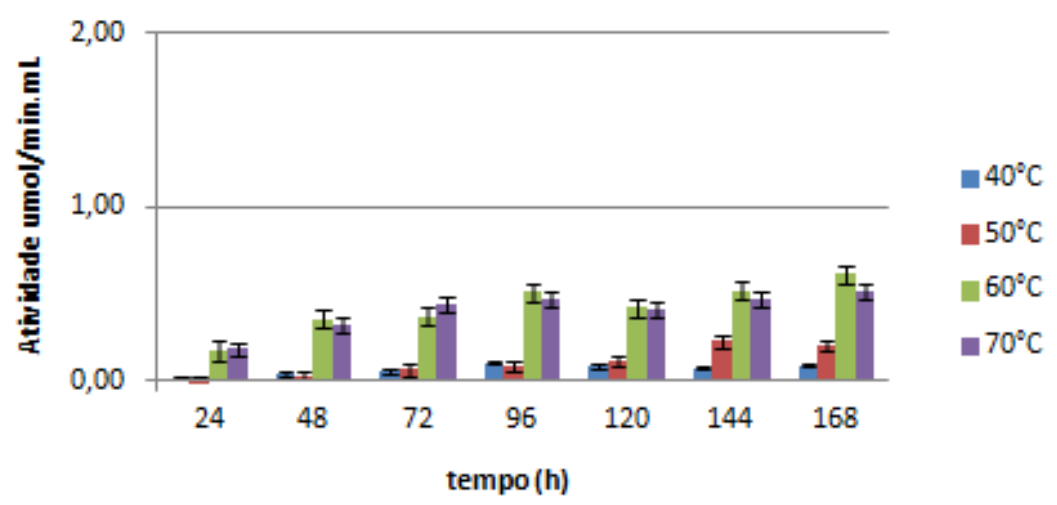

Figura 16 - Dosagem de xilanase para a linhagem A82 sob diferentes temperaturas. Em azul, $40{ }^{\circ} \mathrm{C}$, em vermelho, $50{ }^{\circ} \mathrm{C}$, em verde, $60{ }^{\circ} \mathrm{C}$ e em roxo a temperatura de $70{ }^{\circ} \mathrm{C}$.

Para a linhagem E4.1 (Figura 13), a melhor temperatura foi de $60^{\circ} \mathrm{C}$ a $70^{\circ} \mathrm{C}$ e seus picos foram vistos em 120 horas e 168 horas.

Na Figura 14, a linhagem SoWT teve a sua melhor atividade em temperatura de $60{ }^{\circ} \mathrm{C}$ em 168 horas. Um pico em 24 horas à $40{ }^{\circ} \mathrm{C}$ também chama a atenção porém, este pode ser relativo a possíveis erros de manuseio. O mesmo ocorre com as linhagens C07 e A82 (Figuras 15 e 16, respectivamente), onde a melhor temperatura em todos os tempos foi de $60{ }^{\circ} \mathrm{C}$, mas apresentando maior pico de atividade em 168 horas.

É possível afirmar que todas as linhagens tiveram suas melhores atividades para xilanase a uma temperatura de $60{ }^{\circ} \mathrm{C}$ e em um tempo de 168 horas. Contudo, observando os valores das atividades, é possível verificar que as linhagens SoWT e C07 apresentaram uma atividade mais alta que as outras duas linhagens (E4.1 e A82). A linhagem A82 apresentou a menor taxa de atividade enzimática.

\subsubsection{Influência da temperatura na atividade de endoglicanase}

As Figuras 17 a 20, referem-se às atividades de endoglicanase pelos actinomicetos em diferentes temperaturas e induzidos com CMC. 


\section{Linhagem E4.1}

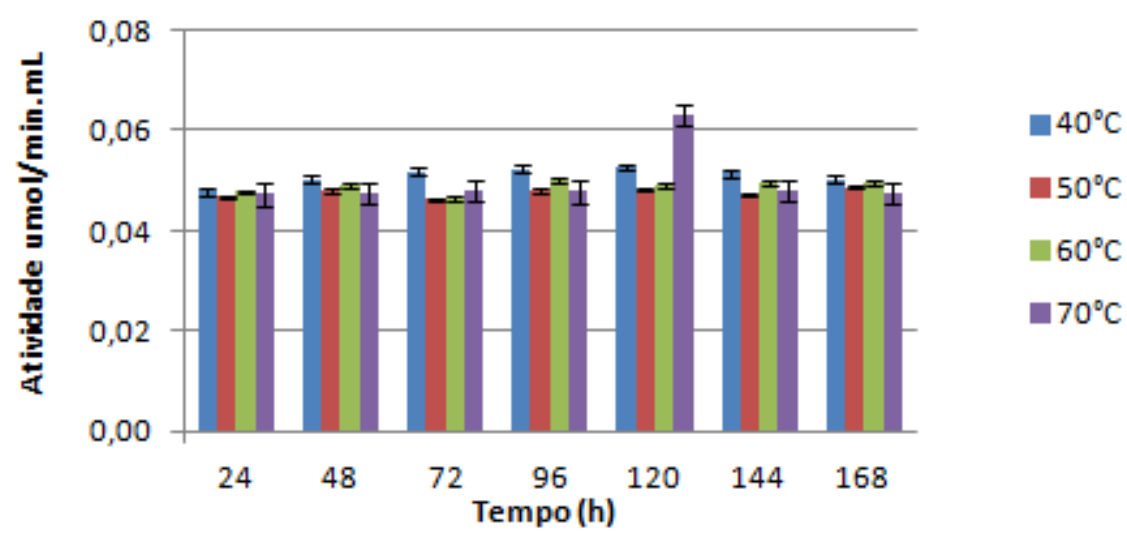

Figura 17 - Dosagem de endoglicanase para a linhagem E4.1 sob diferentes temperaturas. Em azul $40{ }^{\circ} \mathrm{C}$, em vermelho $50{ }^{\circ} \mathrm{C}$, em verde $60^{\circ} \mathrm{C}$ e em roxo a temperatura de $70{ }^{\circ} \mathrm{C}$

\section{Linhagem SoWT}

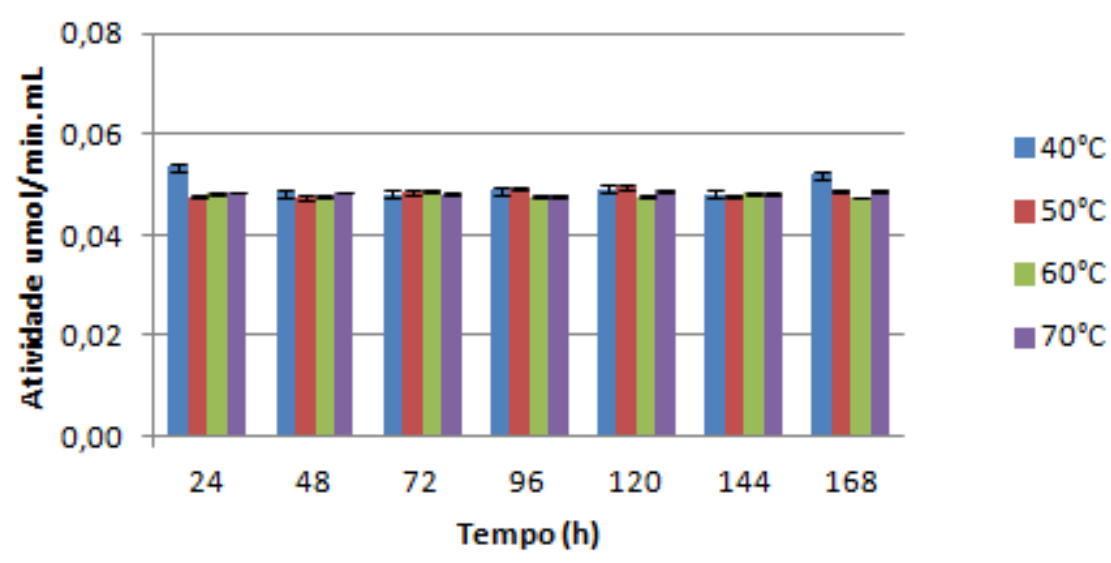

Figura 18 - DEosagem de endoglicanase para a linhagem de Streptomyces olindensis sob diferentes temperaturas. Em azul $40{ }^{\circ} \mathrm{C}$, em vermelho $50{ }^{\circ} \mathrm{C}$, em verde $60{ }^{\circ} \mathrm{C}$ e em roxo a temperatura de $70{ }^{\circ} \mathrm{C}$ 


\section{Linhagem C07}

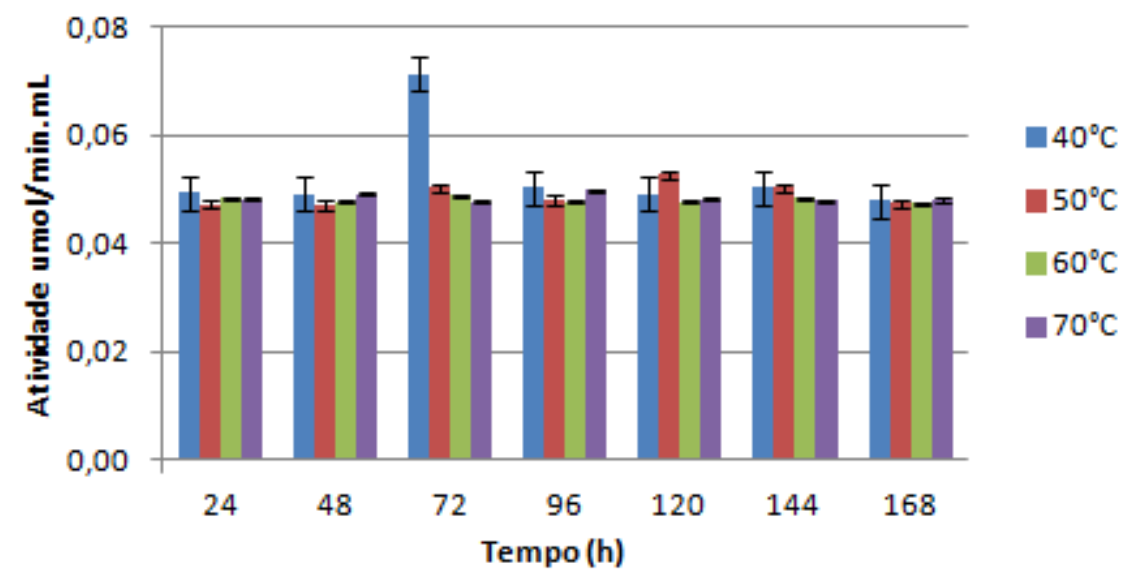

Figura 19 - Dosagem de endoglicanase para a linhagem C07 sob diferentes temperaturas. Em azul $40{ }^{\circ} \mathrm{C}$, em vermelho $50^{\circ} \mathrm{C}$, em verde $60^{\circ} \mathrm{C}$ e em roxo a temperatura de $70{ }^{\circ} \mathrm{C}$.

\section{Linhagem A82}

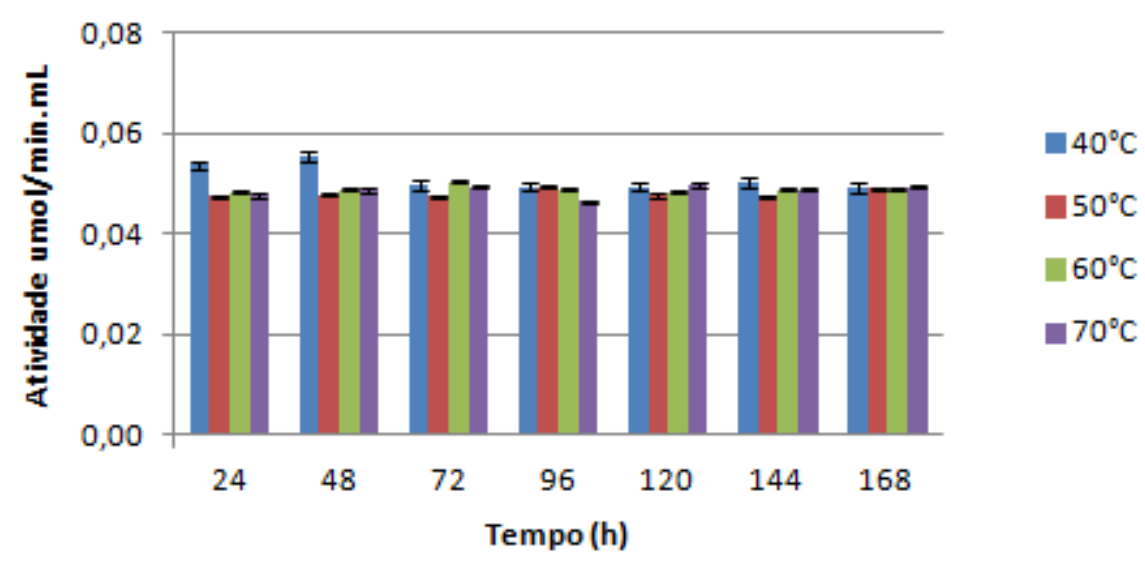

Figura 20 - Dosagem de endoglicanase para a linhagem A82 sob diferentes temperaturas. Em azul $40{ }^{\circ} \mathrm{C}$, em vermelho $50^{\circ} \mathrm{C}$, em verde $60^{\circ} \mathrm{C}$ e em roxo a temperatura de $70{ }^{\circ} \mathrm{C}$

A linhagem E4.1 (Figura 17) teve um pico de atividade em 120 horas a uma temperatura de $70^{\circ} \mathrm{C}$. Na Figura 18, a linhagem SoWT apresenta a formação de dois picos em tempos distintos. O primeiro pico se deu em 24 horas e o segundo em 169 horas, mas ambos a $40{ }^{\circ} \mathrm{C}$. A Figura 19 ilustra o comportamento da linhagem C07, que claramente apresenta um pico de atividade em 72 horas e temperatura de $40^{\circ} \mathrm{C}$. Já para a linhagem A82 (Figura 20), assim como ocorreu com a linhagem SoWT, dois picos também foram visualizados, onde, o 
primeiro em 24 horas e o segundo em 48 horas, ambos em $40{ }^{\circ} \mathrm{C}$, entretanto o pico apresentado em 48 horas se destaca sobre o pico de 24 horas.

Foi observado durante a análise dos dados que para as atividades de xilanase as melhores temperaturas foram de $60{ }^{\circ} \mathrm{C}$ e $70{ }^{\circ} \mathrm{C}$, a maioria dos picos detectados para as atividades de endoglicanase foram a $40{ }^{\circ} \mathrm{C}$. Comparativamente, as linhagens apresentaram melhor produção de xilanase do que para endoglicanase. Devido a esses resultados e a fim de conhecer melhor as xilanases dos actinomicetos testados, estas foram isoladas em gel de SDSPAGE seguido de um sequenciamento de proteínas.

\subsubsection{Influência de pH na atividade de xilanases e endoglicanases}

Para a determinação do melhor $\mathrm{pH}$, foi selecionado para cada linhagem somente a sua melhor temperatura e então a partir dos picos das temperaturas ideais é que os testes com as variações de $\mathrm{pH}$ foram realizadas. As Figuras 21 e 22 apresentam os resultados para o $\mathrm{pH}$.

\section{Xilanase - pH}

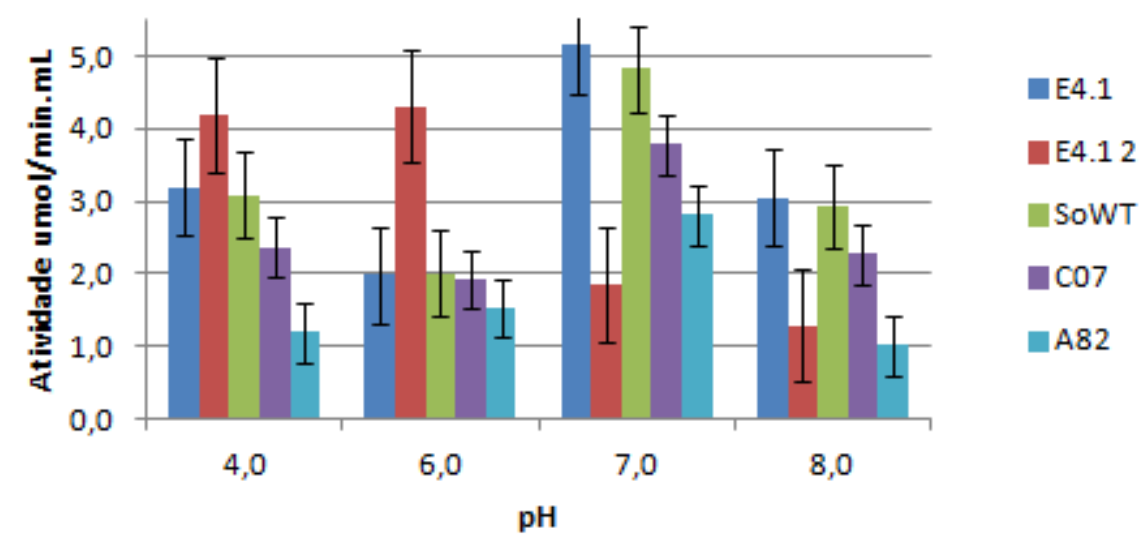

Figura 21 - Amostras selecionadas e seus picos de atividade dependendo do $\mathrm{pH}$ para as xilanases. Em azul, a linhagem E4.1, em vermelho uma segunda amostra de E4.1, em verde, Streptomyces olindensis, em roxo, C07 e em azul claro a amostra da linhagem A82. 


\section{Endoglicanase - pH}

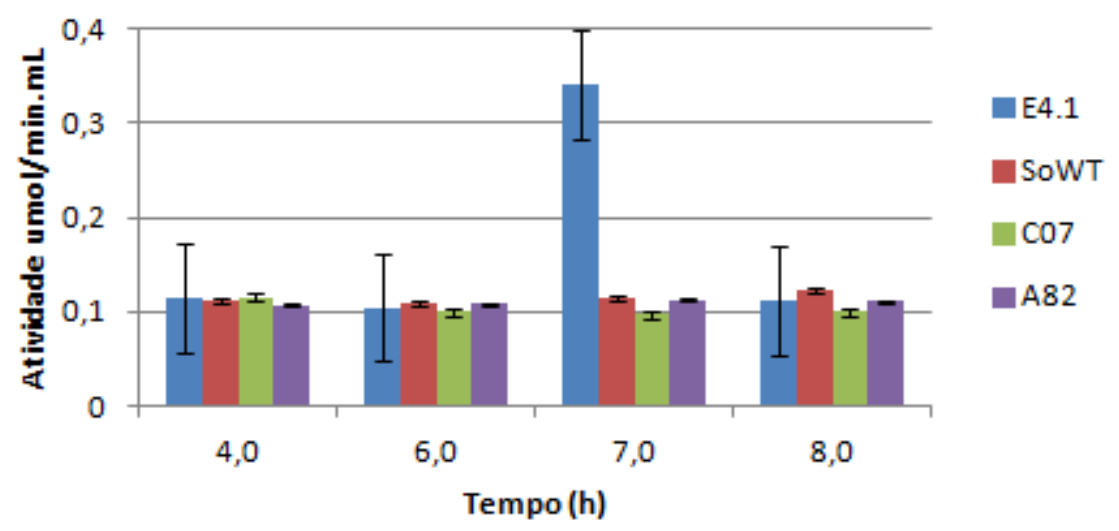

Figura 22 - Linhagens selecionadas e seus picos de atividade dependendo do pH para as endoglicanases. Em azul, a linhagem E4.1, em vermelho - Streptomyces olindensis, em verde - C07 e em roxo a linhagem A82.

No caso do $\mathrm{pH}$, para cada atividade mensurada por indutor xilana, cada linhagem apresentou uma característica, o pico de atividade de E4.1 se deu na faixa de $\mathrm{pH}$ de 4,0 a 7,0, e as linhagens SoWT, C07 e A82 tiveram igualmente uma melhor produção em pH 7,0. Para o CMC, as linhagens tiveram características semelhantes em relação a todas as faixas de pH, com exceção da linhagem E4.1 que apresentou um pico quando testado com pH 7,0. Os resultados, mostram que cada linhagem atingiu sua melhor de produtividade em determinado tempo de cultivo e em determinada temperatura e $\mathrm{pH}$.

As dosagens feitas com o resíduo de p-nitrofenol, não apresentaram um bom resultado, pois todas as amostras tanto para a $\beta$-glicosidase quanto para a arabinofuranosidase tiveram sua absorbância real inferior a absorbância do controle, significando que o espectro apresentado nas amostras foi aquém dos valores apresentados na curva padrão de pNP. Já nas amostras mensuradas por DNS os espectros foram o suficiente para as dosagens.

\subsubsection{Eletroforese em gel de poliacrilamida (SDS-PAGE 12\%)}

Para uma breve caracterização das enzimas que foram triadas, as quatro linhagens selecionadas (E4.1, SoWT, C07 e A82) passaram por um processo de indução das enzimas com meio contendo Xilana. As amostras foram coletadas em 7 dias em um volume de $100 \mathrm{~mL}$ e logo concentradas à um volume de $25 \mathrm{~mL}$. Após, foram conduzidas a uma etapa de 
precipitação com TCA e em seguida as amostras prontas foram aplicadas no gel, a Figura 23 mostra o gel de proteínas realizado com as amostras induzidas.

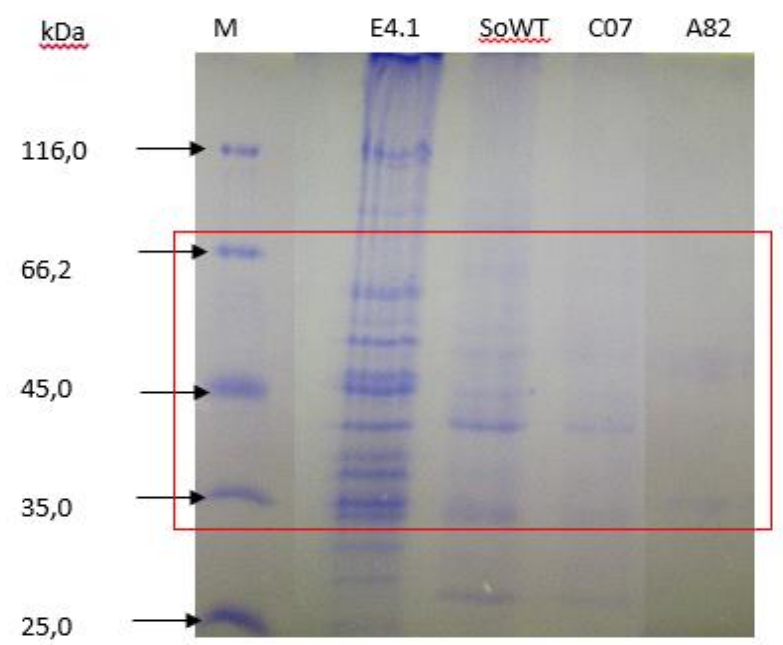

Figura 23 - Gel de proteínas realizado a partir de extrato proteico para as quatro linhagens selecionadas (E4.1, Streptomyces olindensis, C07 e A82), o quadro em vermelho destaca a faixa de tamanho das prováveis xilanases.

\subsubsection{Sequenciamento de proteínas}

As amostras foram cortadas do gel em uma faixa que foi comparada com a literatura existente para o gênero e para as enzimas. A faixa variou de 35.0 a $66.2 \mathrm{kDa}$ e foram sequenciadas. As sequências de aminoácidos estão apresentadas na Tabela 4. 
Tabela 4 - Sequência de aminoácidos encontrados no sequenciamento das proteínas presentes nas linhagens E4.1, SoWT, C07 e A82

\begin{tabular}{|c|c|c|}
\hline Linhagem & Sequência & ID \\
\hline \multirow[t]{7}{*}{ E4.1 } & IVQWDVVNEAFADGSSGAR & \multirow[t]{4}{*}{ Endo-1,4-beta-xylanase $\mathrm{A}$} \\
\hline & TQAMYNMVR & \\
\hline & YFGTAIASGR & \\
\hline & IDATEPQR & \\
\hline & GTVTSDGGTYDIYK & \multirow[t]{3}{*}{ Endo-1,4-beta-xylanase $\mathrm{E}$} \\
\hline & TFDQYWSVR & \\
\hline & NTGNFVAGK & \\
\hline SoWT & TFDQYWSVR & Endo-1,4-beta-xylanase B \\
\hline $\mathrm{C} 07$ & TFDQYWSVR & Endo-1,4-beta-xylanase $B$ \\
\hline \multirow[t]{4}{*}{ A82 } & VYNWAVQNGK & \multirow[t]{4}{*}{ Endo-1,4-beta-xylanase $\mathrm{A}$} \\
\hline & VQIYSCWGGDNQK & \\
\hline & YFGTAIASGR & \\
\hline & IDATEPQR & \\
\hline
\end{tabular}

É possível observar que todas as linhagens apresentaram sequências de uma xilanase, porém, com variações. Não foram encontradas sequências de arabinofuranosidases com indução por xilana, isso pode ter ocorrido devido ao peso molecular da enzima arabinofuranosidase que poderia não estar dentro da faixa de pesos que foi sequenciada. $\mathrm{Na}$ Tabela 4 ainda é possível observar que a linhagem E4.1 apresentou 4 sequências para Xilanase A e 3 sequências para Xilanase B. SoWT e C07 apresentaram cada uma 1 sequência de xilanase B e A82 apresentou 4 sequências para Xilanase A, sendo duas delas similares a duas também identificadas em E4.1.

Ao comparar os resultados obtidos pela árvore filogenética de xilanase e o sequenciamento de proteínas pôde-se observar que A82 e C07 são similares e encontram-se 
no mesmo grupo da árvore filogenética, porém no sequenciamento de proteínas essas não compartilham os domínios de xilanase. A linhagem E4.1 apresenta-se separadamente das outras linhagens porém as mais similares foram H4P4, A12.1 e G10P4 que estão em um grupo mais próximo, mas não seguiram até essa fase do estudo. Já a linhagem SoWT não teve bons resultados do sequenciamento de nucleotídeos e então não pôde ser utilizado na construção da árvore filogenética do gene que codifica para a enzima xilanase. No entanto quando a linhagem SoWT foi submetida ao sequenciamento de proteínas, foi revelada uma sequência de xilanase $B$ e não foi detectada xilanase A. Esse estudo comparativo foi importante para complementar dados obtidos desde as triagens iniciais. O processo de sequenciamento de proteínas para identificação de endoglicanase, arabinofuranosidase e $\beta$ glicosidase não foi viável por demanda de tempo e gastos. 


\section{DISCUSSÃO}

Durante a triagem em meio sólido, observou-se a presença de resultados falso positivo, o fato do controle positivo ter apresentado halo de hidrólise com a solução de lugol, mas, não apresentar na presença da solução de vermelho congo, deve-se principalmente à presença de amido no farelo de trigo e da baixa capacidade de coloração da hemicelulose presente no próprio farelo de trigo pelo vermelho congo. Zitomer e Eveleigh (1986) realizaram a seleção de linhagens produtoras de celulases pela coloração com iodo. Esses autores verificaram que o uso de lugol revela zonas de hidrólise não referentes a uma atividade celulósica, mas, referente à degradação do amido residual presente no ágar comercial.

A princípio as amostras foram analisadas individualmente, medindo-se o halo de hidrólise em cada substrato testado. Este halo foi mensurado para o subsequente cálculo do índice enzimático do qual utilizou a expressão IE = diâmetro do halo/ diâmetro da colônia, como mostrado em Material e Métodos. Para Florencio et al., (2013), as linhagens que apresentam IE mais alto que 1,50 são consideradas como potencial produtoras de celulases. No presente trabalho, julgaram-se como melhores linhagens aquelas que obtiveram índices próximos ao valor máximo conseguido. Assim, para a hidrólise de CMC, oito linhagens (H4P4, G10P4, A12.1, A21, E4.1, C07, A82 e SoWT) se destacaram por terem o valor do índice acima das outras linhagens testadas, entre elas, a que mais chamou a atenção foi uma linhagem encontrada em solo (Streptomyces capoamus) e entre o grupo de endofíticos a linhagem A04 (Nocardiopsis sp.) se sobressaiu. As linhagens E4.1 e B6P4, ambas do gênero Streptomyces, sendo a primeira isolada de fonte desconhecida e a segunda isolada da rizosfera de cana-de-açúcar. Já com o licor como substrato, a linhagem Streptomyces galileus NRRL 2272 isolada de solo e C07 (Streptomyces sp.) isolada de cacau ficaram em evidência. Robl et al., (2013), bioprospectaram fungos para a produção de xilanases e ao comparar os resultados obtidos em testes em meio sólido por esse grupo e os resultados obtidos no presente trabalho, verificou-se que as linhagens de fungos apresentaram índices de hidrólise inferiores aos das bactérias estudadas aqui. Por outro lado, os resultados do teste para a bioprospecção de beta-glucosidades (EDGA), os fungos de Robl e colaboradores (2013), ficam em evidencia sobre as bactérias, já que apresentam indíces acima dessas. As linhagens estudadas que apresentaram alguma importância no teste de difusão de esculina, são na sua maioria isoladas de Citrus sinensis (laranjeira). Segundo Strobel et al. (2004) a planta hospedeira, pode ter relevância sobre os resultados, já que funciona como um ecossistema que influencia o metabolismo dos micro-organismos. Outro experimento também comparado com 
os resultados obtidos por Robl et al. (2013) foram os testes em meio líquido BED+FS, onde novamente os fungos se mostraram superiores as bactérias para a enzima $\beta$-glicosidase, o que contradiz o que Coelho e Nascimento, (2008) e Lima et al., (2005) propuseram, que as características das celulases produzidas por actinomicetos são melhores que aquelas produzidas por fungos em termos de estabilidade da enzima e a alta atividade sob condições de $\mathrm{pH}$ e temperatura mais extremas, por outro lado, há o fator de que os fungos são os endofíticos mais frequentemente isolados (STROBEL; DAISY, 2003), isso pode acontecer por fungos e plantas possuírem mecanismos celulares mais semelhantes entre si.

Encerrando a bioprospecção em meio sólido e em frascos agitados, foi realizada a triagem molecular, porém, não foram encontrados dados na literatura sobre esse tipo de bioprospecção. Na literatura, os autores visam bioprospectar clones de determinada espécie que participam da síntese de algum produto seja ele como precursor ou que gere um produto final, formando assim uma biblioteca genômica, como nos trabalhos de Fernándes-Abadalo et al., (1992) e Perez-Pons et al., (1994), ou por meio da metodologia descrita no trabalho de Edlund et al., (2011), que faz a utilização de T-RFLP. A triagem molecular, no entanto, ajudou a ver que as linhagens em sua grande maioria foram reconhecidas pelos iniciadores para as enzimas e amplificaram as sequências das enzimas estudadas. Linhagens que em testes em meio sólido e em frascos agitados não conseguiram apresentar um valor de importância, conseguiram por meio das amplificações gerar amplicons e mostrar que os genes estão presentes nos indivíduos, como no caso da linhagem A14 (Nocardiopsis sp.), onde o índice de hidrólise para CMC e xilana foi igual a 1,00 e para o licor igual a zero. No estudo de Mackenzie et al., (1987), onde 2 linhagens de Streptomyces foram estudadas (S. flavogriseus e S. olivochromogenes) foi verificado que cada um desses micro-organismos apresentam um comportamento diferente um do outro e rendem atividade para a hidrólise de outros componentes da xilana, e essas atividades ainda podem ser produzidas em alguns casos em múltiplas formas. Isso explica a discrepância entre os testes realizados em meio sólido, em frascos agitados e na triagem molecular.

Quanto as árvores filogenéticas, essas foram analisadas e aquelas linhagens que obtiveram uma identidade abaixo de $70 \%$ foram consideradas muito distantes e, portanto mais interessantes sob ponto de vista de se obter uma sequência ainda não estudada. No caso da primeira árvore, com as amostras para a sequência de uma endoglicanase, a linhagem A82 pode conter uma sequência nova. Já no caso da beta-glucosidase não houve uma linhagem que se destacasse por ser distinta das outras. A linhagem A21, pelo contrário, obteve $98 \%$ de 
identidade, ou seja, sua sequência é muito próxima a sequência da outra linhagem. A árvore filogenética do grupo da xilanase apresentou valores bem divergentes e abaixo dos $70 \%$ que foram estabelecidos. E para a arabinofuranosidase as linhagens A12.1, E4.1 e SoWT se distinguem das outras. Para os endofíticos esses genes podem não estar ativos, pois essas enzimas poderiam alterar o ciclo de vida da planta, ocasionando a morte precoce dessas, já que sua parede celular seria destruída, ou seja, o que pode ocorrer é em relação as sequências encontradas, essas podem não ser novas, mas possuírem determinadas bases que alterem a enzima, tornando-as não funcionais, contudo, na literatura ainda não há estudos moleculares para as enzimas celulolíticas de micro-organismos endofíticos.

Após o processo de seleção, a breve caracterização foi iniciada, testes para temperatura e $\mathrm{pH}$ foram realizados, porém não estudou-se a estabilidade da enzima, pois demandaria de mais custos. As informações obtidas por meio dos resultados foram comparadas com dados encontrados em literatura. A Tabela 7 (Anexo D) apresentada nessa discussão traz um histórico de linhagens, temperaturas e pHs ótimos para atividade de xilanase, Pode-se observar que na sua maioria os estudos realizados revelam que a temperatura ótima foi de $60{ }^{\circ} \mathrm{C}$ e $\mathrm{pH}$ variando de 6,0 a 6,5. Mas, a linhagem E4.1 (Streptomyces sp.) pertencente a este trabalho, fica em evidência pois conseguiu uma temperatura ótima acima dos valores de outras linhagens, chegando a $70{ }^{\circ} \mathrm{C} \mathrm{em} \mathrm{um} \mathrm{pH}$ neutro. A Tabela 8 (Anexo E) mostra os dados obtidos para endoglicanase. Em geral a temperatura ótima para endoglicanases descritas é em torno de $50^{\circ} \mathrm{C}$. A linhagem apresentada no trabalho de Cirigliano, (2013) mostrou que uma linhagem de Streptomyces (Streptomyces misionensis PESB-25) apresentou uma atividade ótima em $70{ }^{\circ} \mathrm{C}$ e pH 3,0, assim como a temperatura apresentada pela linhagem E4.1 do presente trabalho, contudo essa apresentou atividade em todos os pHs testados, sem destaque para nenhum. Um dado que chamou a atenção é que no caso da endoglicanase as bactérias isoladas de plantas, apresentaram um perfil dessas enzimas com atividade em temperaturas mais brandas, enquanto que as bactérias isoladas de solo obtiveram suas atividades em temperatura mais elevadas. Nesse caso cogitouse a possibilidade de que a temperatura de onde os micro-organismos foram isolados influencia diretamente na secreção das enzimas lignocelulolíticas. Segundo Lucht e Ghizoni (1978), a planta, por ser um organismo que transforma a radiação solar em matéria, apresenta temperatura diferente da temperatura do ar. E essa determinação de temperatura depende dos diversos fatores envolvidos nos processos fisiológicos. Segundo Soccol et al. (2010), o processo de hidrólise enzimática na indústria de bioetanol, deve ser realizada em temperaturas 
mais altas devido maior estabilidade das enzimas. melhorar rendimentos e minimizar contaminações. Dessa maneira, as enzimas secretadas pelos micro-organismos deste trabalho, tem o perfil procurado pela indústria do etanol de segunda geração. Entretanto, apesar dos micro-organismos apresentarem boa atividade para enzimas como as xilanases e endoglicanases, a enzima beta-glucosidase, assim como nos ensaios iniciais, não apresentou espectro de detecção pelo método utilizado, dados encontrados na literatura, revelam que, com exceções, algumas bactérias não produzem celobiohidrolases e adiante não formam $\beta$ gIIcosidades extracelulares. As endoglicanases endocelulares bacterianas, quebram a celulose em cadeias menores de oligossacarídeos (FILHO, 2008)

Quanto ao gel de poliacrilamida, realizado para verificar as xilanases das quatro linhagens selecionadas, foi feito o sequenciamento e esse mostrou que as linhagens possuem domínios de xilanases, mas, ainda não é possível afirmar que são melhores das enzimas já encontradas até hoje. 


\section{CONCLUSÃO}

- Os actinomicetos endofíticos têm-se mostrado potencialmente bons produtores de enzimas lignocelulolíticas;

- Quatro linhagens estudadas tiveram maior destaque na produção das enzimas e merecem mais atenção, sendo uma delas não endofítica;

- Dentre as enzimas estudadas, xilanase foi a que apresentou maiores atividades enzimáticas sob diferentes condições de temperatura e $\mathrm{pH}$, até o presente momento, a estabilidade da enzima não foi estudada;

- O estudo de enzimas lignocelulolíticas em micro-organismos endofíticos é uma abordagem nova, há poucos estudos relatados na literatura;

- Os micro-organismos endofíticos, portanto, são interessantes para a produção de enzimas celulolíticas e hemicelulolíticas, podendo essas ser empregados para o uso em processos para a obtenção de etanol de segunda geração e em outros segmentos biotecnológicos. 


\section{REFERÊNCIAS*}

ANDERSON, A. S.; WELLINGTON, E. M. H. The taxonomy of Streptomyces and related genera. International Journal of Systematic and Evolutionary Microbiology. 51(3):797-814, 2001.

ANDRIELLI, F. Bioprospecção de genes envolvidos na síntese de PKS tipo III em micro-organismos endofíticos, 2010, 109 f. Tese (Doutorado em Biotecnologia) - Instituto de Ciências Biomédicas, Universidade de São Paulo, 2010.

ARO, N.; PAKULA, T.; PENTTILÄ, M.. Transcriptional regulation of plant cell wall degradation by filamentous fungi. FEMS Microbiology Reviews. 29(4):719-735, 2005.

AZEVEDO, J. L. Micro-organismos Endofíticos. In: MELO, I. .S.; AZEVEDO, J. L. Ecologia Microbiana. Embrapa-Jaguariúna. EMBRAPA CNPMA, pp. 117-136, 1998.

BON, E. P. S.; GÍRIO, F.; PEREIRA JUNIOR, N. Enzimas na produção de etanol. In: BON, E. P. S. Enzimas em Biotecnologia: Produção, Aplicações e Mercado. 2008, Cap. 10 p 241-271.

BUCKRIDGE, M. S.; SANTOS, W. D.; SOUZA, A. P. As rotas para o etanol celulósico no Brasil, 2008. In: Cortez, L.A.B, Bioetanol de cana-de-açúcar. Estratégias de políticas para o etanol. Blucher. FAPESP. Parte 3, capítulo 7, páginas 365-380, 2010.

CARVALHO LIMA K. G. Fermentação de resíduos por Escherichia coli KO11: influência do inóculo, suplemento nutricional e neutralização do hidrolizado. 2001, 122 f, Dissertação (Mestrado. s em Biotecnologia) - Instituto de Ciências Biomédicas, Universidade de São Paulo, 2001.

CASTRO, A. M; JUNIOR, N. P; Produção, propriedades e aplicação de celulases na hidrólise de resíduos agroindustriais. Química Nova. 33(1): 181-188, 2011.

CHELLAPANDI, P; JANI, H. M. Production of endoglucanase by the native strains of Streptomyces isolates in submerged fermentation. Brazilian Journal of Microbiology. 39(1): 122-127, 2008.

CIRIGLIANO, M. N. F; REZENDE, R. C; OLIVEIRA, M. P. G; PEREIRA, P. H. F; NASCIMENTO, R. P; BON, E. P. S; MACRAE, A; COELHO, R. R. R. Streptomyces misionensis PESB-25 Produces a Thermoacidophilic Endoglucanase Using Sugarcane Bagasse and Corn Steep Liquor as the Sole Organic Substrates. BioMed Research International. 2013:584207. DOI: 10.1155/2013/584207, 2013.

COELHO, R. R. R.; NASCIMENTO, R. P. Seleção de actinomicetos produtores de enzimas de interesse biotecnológico. BON, E. P. S. In: Enzimas em Biotecnologia: Produção, Aplicações e Mercado. Cap. 4 p 71-94.

COLLINS, T; GERDAY, C; FELLER, G. Xylanases, xylanase families and extremophilic xilanases. FEMS Microbiology Reviews. 29(1): 3-23, 2005.

COOMBS, J. T. and FRANCO, C. M. M.. Visualization of an Endophytic Streptomyces Species in Wheat Seed. Applied and Environmental Microbiology, 69(7): 4260-4262, 2003.

\footnotetext{
*De acordo com:

ASSOCIAÇÃO BRASILEIRA DE NORMAS E TÉCNICAS. NBR 6023: informação e documentação: referências: elaboração. Rio de Janeiro, 2002.
} 
DA VINHA, F. N. M; OLIVEIRA, M. P. G; FRANCO, M. N; MACRAE, A; BON, E. P. S; NASCIMENTO, R. P; COELHO, R. R. R. Cellulase Production by Streptomyces viridobrunneus SCPE-09 Using Lignocellulosic Biomass as Inducer Substrate. Applied Biochemestry and Biotechnology. 164(3): 256-267, 2011.

DAVIES, G; HENRISSAT, B. Structures and mechanisms of glycosyl hydrolases. The wealth of information provided by the recent structure determinations of many different glycosyl hidrolases shows that the substrate specificity and the mode of action of these enzymes are governed by exquisite details of their three-dimensional structures rather than by their global fold. Structure. 3(9): 853-859, 1995.

DEDINI S.A. Indústria de Base. Disponível em: <http://www.dedini.com.br〉. Acesso em 2011.

DELABONA, P. S; FARINAS, C. S.; LIMA, D. J. S.; PRADELLA, J. G. C.. Experimental mixture design as a tool to enhance glycosyl hydrolases production by a new Trichoderma harzianum P49P11 strain cultivated under controlled bioreactor submerged fermentation, Bioresource Technology. 2012.

EDLUND, A; LOESGEN, S; FENICAL, W; JENSEN, P. R; Geographic distribution of secondary metabolic genes in the marine Actinomycete Salinispora arenicola. Applied and Environmental Microbiology. 77(17): 5916-5925, 2011.

ELEGIR, G; SZAKÁCS, G; JEFFRIES, T. W. Purification, characterization, and substrate specifities of multiple xylanases from Streptomyces sp. strain B-12-2. Applied and Environmental Microbiology. 60(7):2609-2615, 1994.

El-TARABILY, K. An endophytic chitinase-producing isolate of Actinoplanes missouriensis with potential for biological control of root rot of lupin caused by Plectosporium tabacinus. Australian Journal of Botany, 51:257-266, 2003.

FERNÁNDEZ-ABALOS, J. M; SÁNCHEZ, P; COLL, P. M; VILlANUEVA, J. R; PÉREZ, P; SANTAMARIA, R. I. Cloning and nucleotide sequence of celA1, an Endo- $\beta$-1,4-glucanase encoding gene from Streptomyces halstedii JM8. Journal of Bacteriology. 174(20): 6368-6376, 1992.

FILHO, R. L; FERRO, H. M, PINHO, R. S. C. Controle biológico por Bacillus subtilis. Revista Tropical - Ciências Agrárias e Biológicas. V.4, N2, p. 12, 2010.

FLORENCIO, C; COURI, S; FARINAS, C. S. Correlation between agar plate screening and solidstate fermentation for the prediction of celulase production by Trichoderma strains. Enzyme Research. Volume 2012. Article ID 793708, 7 páginas. Disponível em: http://dx.doi.org/10.1155/2012/793708. Acesso em Fevereiro de 2014.

FUENTES-RAMIREZ, L. E.; JIMENEZ-SALGADO, T.; ABARCA-OCAMPO, I. R.; CABALLERO-MELLADO, J. Acetobacter diazoprophicus, an indol acetic acid producing bacterium isolated from sugarcane cultivars of México. Plant and Soil 154:145-150, 1993.

GAO, D.; CHUNDAWAT, S. P. S.; KRISHNAN, C.; BALAN, V.; DALE, B. E. Mixture optimization of six core glycosyl hydrolases for maximizing saccharification of ammonia fiber expansion (AFEX) pretreated corn stover. Bioresource Technology, 101, 2770-2781, 2010.

GARDA, A. L; FERNÁNDEZ-ABALOS, J. M; SANCHEZ, P; RUIZ-ARRIBAS, A; SANTAMARIA, R. I. Two genes encoding an endoglucanase and a celulose-binding protein are clustered and co-regulated by TTA códon in Streptomyces halstedii JM8. The Biochemical Journal. 324: 403-411, 1997.

GEORGE, S. P.; AHMAD, A.; RAO, M. B.; Studies on carboxymetyl cellulase produced by an alkalothermophilic actinomycete. Bioresource Technology 77(2):171-175, 2001. 
GRABSKI, A. C; JEFFRIES, T. W; Production, Purification and characterization of $\beta-(1-4)-$ Endoxylanase of Streptomyces roseiscleroticus. Applied and Environmental Microbiology. 57(4): 987-992, 1991.

Instituto de Eletrotécnica e Energia, Universidade de São Paulo, Banco de dados de Biomassa no Brasil. Disponível em: http://infoener.iee.usp.br/cenbio/biomassa.htm. Acesso em: 05/03/2014

JACOBSEN S. E.; WYMAN, C. E. Cellulose and hemicellulose hydrolysis models for application to current and novel pretreatment process. Applied Biochemistry and Biotechnology. 84(1-9): 81-96, 2000 .

KASANA, R. C.; SALWAN, R.; DHAR, H.; DUTT, S.; GULATI, A.. A Rapid and Easy Method for the Detection of Microbial Cellulases on Agar Plates Using Gram's Iodine. Current Microbiology. 57, 503-507, 2008.

KESKAR, S. S; SRINIVASAN, M. C; DESHPANDE, V. V. Chemical modification of a xylanase from a thermotolerant Streptomyces. Evidence for essential tryptofan and cysteine residues at the active site. Biochemestry Journal. 206: 49-55, 1989.

KIMURA (1980) A simple method for estimating evolutionary rate of base substitutions through comparative studies of nucleotide sequences. Journal of Molecular Evolution 16:111-120.

LI, N; MENG, K; WANG, Y; SHI, P; LUO, H; BAI, Y; YANG, P; YAO, B. Cloning, expression, and characterization of a new xylanase with broad temperature adaptability from Streptomyces sp. S9. Applied Microbiology and Biotechnology. 80(2): 231-240, 2008.

LIMA A. L. G.; NASCIMENTO, R.P.; BON, E.P.S.; COELHO, R.R.R. Streptomyces drozodewiczii cellulose production using agro-industrial by-products and its potential use in the detergent and textile industries. Enzyme Microbiology and Technology. 37(2):272-277, 2005.

LUCHT, L. A. M; GHIZONI, C. C. Temperatura das plantas - teoria e aplicações em sensoriamento remoto. In: Simpósio Brasileiro de sensoriamento remoto, 1. .(SBSR), 1978, São José dos Campos: INPE, 1978. p. 236-251. Disponível em http://urlib.net/dpi.inpe.br/marte@80/2008/09.23.14.19. Acesso em 10 de Abril de 2014.

LUMYONG, S.; LUMYONG, P.; MCKENZIE, E.H.; HYDE, K.D. Enzymatic activity of endophytic fungi of six native seedling species from Doi Suthep-Pui National Park, Thailand. Canadian Journal of Microbiology. 48(12):1109-12, 2002.

LYND, L. R; WEIMER, P. J; ZYE, W. H. Y; PRETORIUS, I. S. Microbial cellulose utilization: Fundamentals and Biotechnology. Microbiology and Molecular Biology Reviews. 66(3):506-577, 2002.

MACEDO, I. C. ; NOGUEIRA, L. A. H. Biocombustíveis. 1. ed. Brasilia: Núcleo de Assuntos Estratégicos da Presidência da República. v. 1. p. 233, 2005.

MACKENZIE, C. R., BILOUS, D., SCNEIDER, H., and JOHNSON, K. G. Induction of cellulolytic and xylanolytic enzyme systems in Streptomyces spp. Applied Environmental Microbiology. 53(12): 2835-2839, 1987.

MARTIN, C.; GALBE, M., WAHLBOM, C.F.; HAHN-HÄGERDAL, B.; JÖNSON, L.J.; Ethanol production from enzymatic hydrolysates of sugarcane bagasse using xylose-utilising Saccharomyces cerevisiae. Enzyme Microbial Technology, 31(3): 274-282, 2002.

MARTINELLI, L. A; FILOSO, S. Expansion of sugarcane ethanol production in Brazil: Environmental and social challenges. Ecological Applications, 18(4):885-898, 2008

MILLER, G. L. Use of dinitrossalicylic acid reagent for determination of reducing sugar. Analytical Chemestry. 31(3): 426-428. 
MOROSOLI, R. BERTRAND, J. L; MONDOU, F; SHARECK, F; KLUEPFEL, D. Purification and properties of a xylanase from Streptomyces lividans. Biochemestry Jounal. 239: 587-592, 1986.

MOY, M.; LI, H. M.; SULLIVAN, R.; WHITE, J. F. Jr; Belanger, F.C. Endophytic fungal beta-1,6glucanase expression in the infected host grass. Plant Physiology. 130(3): 1298-308, 2002.

NASCIMENTO, R. P.; COELHO, R. R. R; MARQUES, S.; ALVES, L.; GÍRIO, F. M.; BON, E. P. S.; AMARAL-COLAÇO, M. T. Production and partial characterization of xylanase from Streptomyces sp. Strain AMT-3 isolated from Brazilian cerrado soil. Enzyme and Microbial Technology. 31, 549-555, 2002.

NUMAN, M. T; BHOSLE, N. B. Alpha-L-arabinofuranosidases: The potential applications in biotechnology.; Journal of Industrial Microbiology and Biotechnology. 33(4):247-260, 2006.

PANDEY, A; SOCCOL, C.R; NIGAM, P; SOCCOL, V.T. Biotechnological Potencial of agroindustrial residues. I: sugarcane bagasse. Bioresource Technology. 74(1):69-80, 2000.

PEREZ-PONS, J. A; CAYETANO, A; REBORDOSA, X; LLOBERAS, J; GUASCH, A; QUEROL, E. A $\beta$-Glucosidase gene (bgl3) from Streptomyces sp. strain QM-B814. Molecular cloning, nucleotide sequence, purification and characterization of encoded enzyme, a new member of family 1 glycosil hydrolases. European Journal of Biochemestry. 223(2): 557-565, 1994.

POLIZELI, M. L. T. M.; RIZZATTI, A. C. S.; MONTI, R.; TERENZI, H. F.; JORGE, J. A.; AMORIM, D.S. Xylanases from fungi: properties and industrial applications, Review. Applied Microbiology and Biotechnology, 67:577-591, 2005.

PURCELL, A. H. Homopteran transmission of xylem-inhabiting bacteria. In: Advances in Disease Vector Research. Edited by K. F. Harris. New York. Springer. 243-266, 1990.

ROBL, D; DELABONA, P. S; MERGEL, C. M; ROJAS, J. D; COSTA, P. S; PIMENTEL, I. C; VICENTE, V. A; PRADELlA, J. G. C; PADILLA, G. The capability of endophytic fungi for production of hemicellulases and related enzymes. BMC Biotechnology. 2013, 13-94. DOI: 10.1186/1472-6750-13-94.

SAHA, B. C. Hemicellulose bioconversion. Journal of Industrial Microbiology and Biotechnology. Review paper. 30(5):279-291, 2005.

SAQIB, A. A. N; WHITNEY, P. J. Esculin gel diffusion assay (EDGA): A simple and sensitive method for screening $\beta$-glucosidases. Enzyme and Microbial Technology. 39(2): 182-184, 2006.

SARKO, A. Cellulose-How much do we know about its structure? In: Wood and Cellulosics: Industrial Utilization. Biotecnhology, Structure and Properties. John Wiley ; Sons, New York, 1997.

SCHULZ, B.; BOYLE, C. The endophytic continuum. Mycological Research.109(Pt 6):661-86, 2005.

SHALlOM, D.; SHOHAM, Y. Microbial hemicellulases. Current Opinion in Microbiology. 6(3): 219-228, 2003.

SILVA, A. M.; NALON, M. A.; NASCIMENTO, F. J.; KRONKA, C. A.; ÁlVARES, P. B.; CAMARGO, P. B.; MARTINELLI, L.A. Historical land-cover/use in different slope and riparian buffer zones in watersheds of the state of São Paulo, Brazil. Piracicaba, São Paulo, Brasil. Scientia Agricola, 64(4):325-335, 2007.

SILVA, J. C; GOUVEIA, E. R., SOME PROPERTIES OF ENDOGLUCANASES PRODUCED BY STREPTOMYCES SPP. IN MEDIUM BASED ON SUGAR CANE BAGASSE. Revista Brasileira de Tecnologia Agroindustrial, 02 (02): 60-70, 2008. 
SINGH, R.; KUMAR, R.; BISHNOI, K.; BISHNOI, N. R.. Optimization of synergistic parameters for thermostable cellulase activity of Aspergillus heteromorphus using response surface methodology. Biochemical Engineering Journal. 48(1): 28-35, 2009.

SOCCOL, C. R; VANDENBERGHE, L. P; MEDEIROS, A. B; KARP. S. G; BUCKERIDGE, M. RAMOS, L. P; PITARELO, A. P; FERREIRA-LEITÃO, V; GOTTSCHALK, L. M; FERREIRA, M. A; DA SILVA BON, E. P; DE MORAES, L. M; ARAUJO JDE A; TORRES, F. A. Bioethanol from lignocelluloses: Status and perspectives in Brazil. Bioresource technology. 101(13): 4820-4825, 2010.

SOUZA, A.Q.L.; SOUZA, A.D.L.; ASTOLFI FILHO, S.; BELÉM PINHEIRO, M.L.; SAQUIS, M.I.M.; PEREIRA, J.O. Atividade antimicrobiana de fungos endofíticos isolados de plantas tóxicas da Amazônia: Palicourea langiflora (aubl.) rich e Stychnos cogens bentham. Acta Amazonica 34(2):185-195.

STROBEL, G.; DAISY, B.; CATILLO, U.; HARPER, J. Natural products from endophytic microorganisms. Journal of Natural Products, 67(2): 257-268, 2004.

STROBEL, G; DAISY, B. Bioprospecting for microbial Endophytes and their Natural Products. Microbiology and Molecular Biology Reviews. 67(4): 491-502, 2003.

SUlEMAN, P.; L-MUSALlAM, A.; MENEZES, C.A. The effects of biofungicide Mycostop on Ceratocystis radicicola, the causal agent of black scorch on date palm. Biocontrol 47(2):207-216, 2002.

TECHAPUN, C; CHAROENRAT, T; POOSARAN, N; WATANABE, M; SASAKI, K. Thermostable and Alkaline-Tolerant cellulose Free-Xylanase produced by Thermotolerant Streptomyces sp. Ab106. Journal of Bioscience and Bioengineering. 93(4): 431-433, 2002

THÉBERGE, M; LACAZE, P; SHARECK, F; MOROSOLI, R; KLUEPFEL, D. Purification and characterization of an Endoglucanase from Streptomyces lividans 66 and DNA sequence of the gene. Applied and Environmental Microbiology. 58(3): 815-820, 1992.

União da indústria de cana-de-açúcar, ÚNICA. Disponível em: www.unicadata.com.br. Acesso em: $18 / 03 / 2013$

União dos Produtores de Bioenergia, UPOD. Disponível em: http://www.udop.com.br. Acesso em: $10 / 04 / 2013$

WACHINGER, G; BRONNENMEIER, K; SATUDENDOWER, W. L; SCHREMPF, H. Identification of mycelium associated cellulose from Streptomyces reticuli. Applied and Environmental Microbiology. 55(10): 2653-2557, 1989.

WALDRON, C. R.; EVELEIGH, D.E. Saccharification of cellulosics by Microbiospora biospora. Applied Microbiology and Biotechnology. 24(6):487-492, 1986.

WILSON, D. B. Biochemistry and genetics of actinomycete cellulases degradation. Critical Reviews in Biotechnology. 12(1-2):45-63, 1992.

WOOD, P. J. J. D; ERFLE, and R. M. TEATHER. 1988. Use of complex formation between Congo red and polysaccharide in detection and assay of polysaccharide hydrolases. Methods Enzymol. 160: 59-74.

XIAO, Z; STORMS, R; ISANG, A. Microplate- based filter paper assay to measure total celulase activity. Biotechnology and Bioengineering. 88(7): 832-837, 2004.

YENNAMALI, R. M; RADER, A. J; WOLT, J. D; SEN, T. Z. Thermostability in endoglucanases is fold-specific. BMC Structural Biology. DOI: 10.1186/1472-6807-11-10, 2011. 
ZHANG, Y. H. P.; LYND, L.R. Toward an aggregated understanding of enzymatic hydrolysis of cellulose: non-complexed cellulose systems. Biotechnology and Bioengineering. 88(7):797-824, 2004.

ZITOMER, S. W.; EVELEIGH, D. E. Celulase screening by iodine staining: an artfect. Enzyme Microbial Technology. v. 91987 


\section{ANEXOS}

Anexo A - Identificação das linhagens de actinomicetos endofíticos por $16 \mathrm{~S}$ ribossomal e suas fontes de isolamento

\begin{tabular}{|c|c|c|c|}
\hline & $\begin{array}{l}\text { Actinomicetos } \\
\text { Endofíticos }\end{array}$ & $\begin{array}{l}\text { Planta } \\
\text { Hospedeira }\end{array}$ & Result of BLASTn search of amplified 16SrRNA \\
\hline$\overline{1}$ & $\mathrm{~A} 01$ & Citrus reticulate & Streptomyces sp. 304104 FJ262966 \\
\hline 2 & $\mathrm{~A} 03$ & Citrus reticulate & Nocardiopsis sp. EU196477 \\
\hline 3 & $\mathrm{~A} 04$ & Citrus reticulate & Nocardiopsis sp. EU384276 \\
\hline 4 & $\mathrm{~A} 07$ & Citrus sinensis & Nocardiopsis sp. EU384273 \\
\hline 5 & A10 & Citrus reticulate & S. sampsonii EU841629 \\
\hline 6 & A11 & Citrus sinensis & Nocardiopsis sp. EU384273 \\
\hline 7 & $\mathrm{~A} 12,1$ & Saccharum sp. & S. fumanus EU593711 \\
\hline 8 & $\mathrm{~A} 12 \mathrm{P} 2$ & Saccharum sp & Streptomyces sp. C35 DQ085812 \\
\hline 9 & A14 & Citrus sinensis & Nocardia sp. AM411943 \\
\hline 10 & A16 & Citrus sinensis & Uncultured Nocardiopsis sp. clone ntu19 EF153434 \\
\hline 11 & A17 & Citrus sinensis & Nocardiopsis sp. EU384273 \\
\hline 12 & A18 & Citrus sinensis & Streptomyces sp. CLS39 FJ200296 \\
\hline 13 & $\mathrm{~A} 21$ & Citrus sinensis & Streptomyces sp. AB301481 \\
\hline 14 & A22 & Citrus sinensis & Nocardiopsis sp. EU384273 \\
\hline 15 & A23 & Citrus reticulate & Streptomyces sp. CLS39 FJ200296 \\
\hline 16 & A25 & Citrus sinensis & Streptomyces sp. DQ513504 \\
\hline 17 & A26 & Citrus sinensis & Streptomyces sp. CLS39 FJ200296 \\
\hline 18 & A28 & Citrus sinensis & Streptomyces sp. ME03-5709a EU080956 \\
\hline 19 & $\mathrm{~A} 30$ & Citrus sinensis & Streptomyces verne $A B 184727$ \\
\hline 20 & A32 & Citrus sinensis & Streptomyces sp. CLS39 FJ200296 \\
\hline 21 & A3P1 & Saccharum sp & Streptomyces albus subsp. pathocidicus AY999806 \\
\hline 22 & A4P1 & Saccharum sp & Streptomyces pulveraceus strain 173717 FJ481627 \\
\hline 23 & A82 & Saccharum sp & Streptomyces pseudogriseolus FJ486305 \\
\hline 24 & $\mathrm{~B} 01$ & Citrus sinensis & Streptomyces sp. EU181260 \\
\hline 25 & $\mathrm{~B} 6 \mathrm{P} 4$ & Saccharum sp & Streptomyces sp. DQ887329 \\
\hline 26 & $\mathrm{C} 07$ & Theobroma cacao & Streptomyces sp. EU305468 \\
\hline 27 & F7P4 & ND & Streptomyces akiyoshiensis strain FJ486367 \\
\hline 28 & G10P4 & Saccharum sp & S. macrosporeus EF063494 \\
\hline 29 & G1P1 & Saccharum sp & Streptomyces pseudogriseolus FJ486305 \\
\hline 30 & $\mathrm{H} 4.3$ & Saccharum sp & Streptomyces sp. MJM3859 EU603347 \\
\hline 31 & H4P3 & Saccharum sp & S. tsukiyonensis AB184594 \\
\hline 32 & $\mathrm{H} 4 \mathrm{P} 4$ & Saccharum sp & Streptomyces sp. EF012109 \\
\hline
\end{tabular}




\begin{tabular}{|c|c|c|c|}
\hline 33 & A08 & Citrus reticulate & Streptomyces sp. EU263067 \\
\hline 34 & A09 & Citrus sinensis & Streptomyces sp. EU741108 \\
\hline 35 & JR1 & Vinca & S. globisporus \\
\hline 36 & JR3 & Vinca & S. roseochromogenus \\
\hline 37 & - & Solo & Streptomyces capoamus \\
\hline 38 & NRRL2722 & Solo & Streptomyces galilaeus \\
\hline 39 & ССТ2398 & Solo & Streptomyces rimosus \\
\hline 40 & TK21 & Solo & Stretomyces lividans \\
\hline 41 & $\begin{array}{l}\text { So(WT) } \\
\text { DAUFPE } 5622\end{array}$ & Solo & Streptomyces olindenses \\
\hline 42 & $A 3(2)$ & Solo & Streptomyces coelicolor \\
\hline
\end{tabular}


Anexo B -

Meios de cultura

ISP2 - Para selecionar propriedades e procedimentos reprodutíveis para caracterização das espécies de Streptomyces

\begin{tabular}{r|l} 
ISP2 & $g / L$ \\
EXTRATO DE MALTE & 10,0 \\
EXTRATO DE LEVEDURA & 4,0 \\
GLICOSE & 4,0 \\
ÁGAR & 20,0
\end{tabular}

YEME - Meio utilizado para ativação de esporos, preparação de protoplastos e crescimento de Streptomyces spp para realizar extração de DNA

\begin{tabular}{r|l} 
YEME & $G / L$ \\
\hline EXTRATO DE LEVEDURA & 3,0 \\
EXTRATO DE MALTE & 3,0 \\
PEPTONA & 5,0 \\
GLICOSE & 10 \\
SACAROSE & 340 (34\% final)
\end{tabular}

Após autoclavar, adicionar:

- $\mathrm{MgCl} 2.6 \mathrm{H} 2 \mathrm{O}(2,5 \mathrm{M})-2 \mathrm{~mL}$ por litro (5mM final)

Para a preparação de protoplastos , adicionar também:

- Gilicna (20\%) - $25 \mathrm{~mL}$ por litro (0,5\% final)

Meio de Silva e Gouveia, 2008 G/L

$$
\begin{array}{r|l}
\mathrm{NaNO}_{3} & 1,2 \\
\mathrm{KH}_{2} \mathrm{PO}_{4} & 3,0 \\
\mathrm{~K}_{2} \mathrm{HPO}_{4} & 6,0 \\
\mathrm{MgSO}_{4} .7 \mathrm{H}_{2} \mathrm{O} & 0,2 \\
\mathrm{CaCl}_{2} .2 \mathrm{H}_{2} \mathrm{O} & 0,05 \\
\mathrm{MnSO}_{4} \cdot 7 \mathrm{H}_{2} \mathrm{O} & 0,01 \\
\mathrm{ZnSO}_{4} & 0,001 \\
\mathrm{AGAR}_{\mathrm{G}} & 15
\end{array}
$$

KASANA, $2008 \quad G / L$

$$
\begin{array}{l|l}
\mathrm{NaNO}_{3} & 2,0
\end{array}
$$




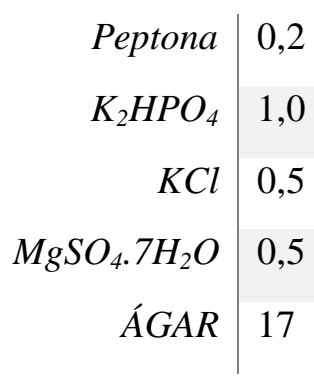

Meio de Nascimento, et al. $2002 \quad$ G/L

\begin{tabular}{r|l} 
Proteose Peptona & 1,0 \\
$\mathrm{Teewn} 80$ & $0,1 \%(\mathrm{v} / \mathrm{v})$ \\
$\mathrm{NaNO}_{3}$ & 1,2 \\
$\mathrm{KH}_{2} \mathrm{PO}_{4}$ & 3,0 \\
$\mathrm{~K}_{2} \mathrm{HPO}_{4}$ & 6,0 \\
$\mathrm{MgSO}_{4} .7 \mathrm{H}_{2} \mathrm{O}$ & 0,2 \\
$\mathrm{CaCl}_{2} .2 \mathrm{H}_{2} \mathrm{O}$ & 0,05 \\
$\mathrm{MnSO}_{4} .7 \mathrm{H}_{2} \mathrm{O}$ & 0,01 \\
$\mathrm{ZnSO}_{4}$ & 0,001 \\
$\mathrm{AGAR}$ & 15
\end{tabular}

Composição do licor do pré-tratamento hidrotérmico da cana de açúcar.

$\begin{array}{lll}\text { Concentração }(G / L) & \text { Licor } & \text { Licor } \\ & \text { hidrotérmico } & \text { hidrotérmico } \\ & & \text { destoxificado }\end{array}$

\begin{tabular}{r|cc} 
Glicose & $0,54 \pm 0,07$ & $0,00 \pm 0,00$ \\
Xilose & $4,7 \pm 0,41$ & $2,48 \pm 0,21$ \\
Celobiose & $0,00 \pm 0,00$ & $0,00 \pm 0,00$ \\
Arabinose & $0,77 \pm 0,10$ & $0,59 \pm 0,01$ \\
Ácido acético & $1,47 \pm 0,18$ & $2,43 \pm 0,30$ \\
Ácido fórmico & $0,23 \pm 0,10$ & $0,18 \pm 0,08$ \\
HMF & $0,18 \pm 0,01$ & $0,00 \pm 0,00$ \\
Furfural & $1,05 \pm 0,06$ & $0,00 \pm 0,00$ \\
Xilo-oligossacarídeo & $9,98 \pm 1,13$ & $4,01 \pm 0,45$ \\
Lignina Solúvel & $3,15 \pm 0,49$ & $1,32 \pm 0,20$
\end{tabular}

Lugol $1 \%-1 \mathrm{~g} / 100 \mathrm{~mL}$ 
Anexo C - Linhagens Padrão

$\begin{array}{lll}\text { Sigla } & \text { Linhagem } & \text { Fonte de isolamento } \\ \text { ATCC25922 } & \text { Escherichea coli } & \text { Isolado clínico } \\ \text { S. griseus } & \text { Streptomyces griséus } & \text { Desconhecido } \\ \text { Sa ATCC } & \text { Streptomyces avermitilis } & \text { Desconhecido } \\ \text { S. } \text { capoamus } & \text { Streptomyces capoamus } & \text { Desconhecido } \\ \text { DSM46458 } & \text { Streptomyces chartresuts } & \text { Desconhecido } \\ \text { NRRL2722 } & \text { Streptomyces galilaeus } & \text { Solo } \\ \text { CCT2398 } & \text { Streptomyces rimosus } & \text { Desconhecido } \\ \text { TK21 } & \text { Stretomyces lividans } & \text { Solo } \\ \text { So(WT }) & \text { Streptomyces olindenses } & \text { Solo }\end{array}$




\section{Anexo D}

Tabela 4 - Dados da literatura e do presente trabalho para comparar a temperatura e $\mathrm{pH}$ da atividade de Xilanase em Streptomyces spp.

\begin{tabular}{llll}
\hline Micro-organismo & $\mathbf{T}^{\circ}$ & $\mathbf{p H}$ & Referencia \\
& $\mathbf{C}$ & & \\
\hline Streptomyces sp. Ab106 & 60 & 6,0 & Techapun et al., 2002 \\
Streptomyces sp. & 60 & 5,5 & Keskar 1989 \\
Strptomyces lividans & 60 & 6,0 & Morosoli, 1986 \\
Streptomyces sp. AMT-3 & 65 & 6,0 & Nascimento, 2002 \\
Streptomyces roseiscleroticus & 60 & 6.5 & Grabski et al., 1991 \\
Streptomyces sp. Linhagem B-12-2 & 60 & 6,0 & Elegir et al., 1994 \\
Streptomyces sp. S9 & 60 & 6,5 & Li et al., 2008 \\
Streptomyces sp. Linhagem E4.1 & 70 & 7,0 & Presente trabalho \\
Streptomyces olindensis & 60 & 7,0 & Presente trabalho \\
Streptomyces sp. Linhagem C07 & 60 & 7,0 & Presente trabalho \\
Streptomyces pseudogriseolus Linhagem A82 & 60 & 7,0 & Presente trabalho \\
\hline
\end{tabular}




\section{Anexo E}

Tabela 5 - Dados da literatura e do presente trabalho para comparar a temperatura e $\mathrm{pH}$ da atividade de Endoglicanase em Streptomyces spp.

\begin{tabular}{llll}
\hline Micro-organismo & $\mathbf{T}^{\circ} \mathbf{C}$ & $\mathbf{p H}$ & Referência \\
\hline Streptomyces spp. & 60 & 4,8 & Cysneiros et al., 2008 \\
Streptomyces viridobrunneus SCPE 25 & 50 & 4,9 & Vinha, 2011 \\
Streptomyces lividans 66 & 34 & $/$ & Théberge, 1992 \\
Streptomyces halstedii JM8 & 50 & 6,0 & Garda, 1997 \\
Streptomyces reticuli & 55 & 7,0 & Wachinger, 1989 \\
Streptomyces sp. Linhagem BRC1 & 30 & $6,5-7,0$ & Chellapandi, 2008 \\
Streptomyces misionensis PESB - 25 & 70 & 3,0 & Cirigliano, 2013 \\
Streptomyces sp. Linhagem E4.1 & 70 & $/$ & Presente trabalho \\
Streptomyces olindensis & 40 & 7,0 & Presente trabalho \\
Streptomyces sp. Linhagem C07 & 40 & 7,0 & Presente trabalho \\
Streptomyces pseudogriseolus Linhagem A82 & 40 & 7,0 & Presente trabalho \\
\hline
\end{tabular}

